AperTO - Archivio Istituzionale Open Access dell'Università di Torino

\title{
Apoptosis in muscle-to-meat aging process: The omic witness
}

\section{This is the author's manuscript}

Original Citation:

\section{Availability:}

This version is available http://hdl.handle.net/2318/1522075

since 2016-02-11T18:37:50Z

Published version:

DOI:10.1016/j.jprot.2015.04.023

Terms of use:

Open Access

Anyone can freely access the full text of works made available as "Open Access". Works made available under a Creative Commons license can be used according to the terms and conditions of said license. Use of all other works requires consent of the right holder (author or publisher) if not exempted from copyright protection by the applicable law. 


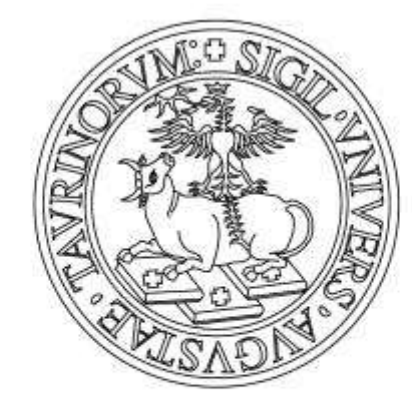

\section{UNIVERSITÀ DEGLI STUDI DI TORINO}

This Accepted Author Manuscript (AAM) is copyrighted and published by Elsevier. It is posted here by agreement between Elsevier and the University of Turin. Changes resulting from the publishing process - such as editing, corrections, structural formatting, and other quality control mechanisms - may not be reflected in this version of the text. The definitive version of the text was subsequently published in

[Journal of Proteomics 125 (2015) 29-40,http://dx.doi.org/10.1016/j.jprot.2015.04.023]

You may download, copy and otherwise use the AAM for non-commercial purposes provided that your license is limited by the following restrictions:

(1) You may use this AAM for non-commercial purposes only under the terms of the CC-BY-NC-ND license.

(2) The integrity of the work and identification of the author, copyright owner, and publisher must be preserved in any copy.

(3) You must attribute this AAM in the following format: Creative Commons BY-NC-ND license

(http://creativecommons.org/licenses/by-nc-nd/4.0/deed.en), [http://dx.doi.org/10.1016/j.jprot.2015.04.023] 
Volume 125, 1 July 2015, Pages 29-40

\title{
Apoptosis in muscle-to-meat aging process: The omic witness
}

- Valentina Longo ${ }^{\mathrm{a}}$,

- $\quad$ Alessandro Lana ${ }^{a}$,

- $\quad$ Maria Teresa Bottero ${ }^{\mathrm{b}}$,

- Lello Zolla ${ }^{\mathrm{a}, \text {, }}$

doi:10.1016/j.jprot.2015.04.023

\section{Highlights}

$\circ \quad$ Omic analysis of aging meat shows physiological impairment of muscle cells.

- Proteomic clues of apoptosis: ANXA2, PEBP, DJ1, HSPB6, ADK, cryaB, and $31 \mathrm{kDa}$ actin fragment

○ Metabolomic clues of apoptosis: key metabolites, nitrotyrosine, and taurine

○ Phosphoproteomic clues of apoptosis: cryaB, HSPB6, myosin 2, and synaptopodin 2

\begin{abstract}
Meat derives from a muscle that undergoes a great number of biochemical and physiological changes. The anoxic condition established from the moment of animal sacrifice forces muscle cells to a sort of reaction, resulting in methodical programmed cell death to avoid necrosis. The duality autophagy and/or apoptosis is at the center of the scientific debate about the biological processes driving the muscle to meat conversion. Here we report an omic time course overview carried on proteome, phosphoproteome and metabolome of Piedmontese longissimus thoracis muscle searching for clues helping us to extricate through the dilemma. The survey depicts a progressive physiological impairing and our evidences push towards the apoptotic behavior: the proteomic time course trend of annexin A2, RKIP, HSPB6, $\alpha \mathrm{B}$ crystalline, adenylate kinase, DJ-1 and $31 \mathrm{kDa}$ actin fragment; the 0-1 day increased phosphorylation of myosin 2 and synaptopodin and the metabolomic time course trend of key metabolic indicators, like GSH/GSSG ratio, taurine and nitrotyrosine. The employed techniques provide strong indications about the likely apoptotic behavior of aging meat in muscle-to-meat conversion process.
\end{abstract}

\section{Biological significance}

Our work underlines compelling evidences of the apoptotic behavior of Piedmontese beef muscle cells undergoing the muscle-to-meat process, whereas no autophagic clues are inferred from this omic investigation.

\section{Graphical abstract}






\section{Keywords}

- $\quad$ Proteomics;

- Phosphoproteomics;

- Metabolomics;

- $\quad$ Beef meat aging;

- $\quad$ Autophagy;

- Apoptosis

\section{Introduction}

Food science constitutes a field of increasing importance that has known a high degree of consideration in the last forty years. Among others, the branch of meat science is one of the most important and fascinating on the scientific side, due to the huge complexity of the processes driving the transformation of muscles into the marketable meat throughout a certain number of physiological changes. This evolution is permitted thanks to the process of 'meat aging', which simply consists in a rest period after slaughter under chilling conditions preventing microbiological unsafety. The slaughtered muscle undergoes molecular changes resumable and subdividable in three phases: (1) pre-rigor phase, (2) rigor phase and (3) tenderization phase; the latter largely depends on aging duration and temperature, muscle types, individual genotype and animal species [1], but the common focal point is the activation of three main families of proteolytic enzymes (calpaines, cathepsins, caspases) driving the destruction of muscle fibers [2], [3], [4] and [5].

Due to the lack of oxygen in the slaughtered muscle, the mitochondrial energy production (in terms of ATP and NADH/NAD + ratio) activity drops down, causing the reactive oxygen species (ROS) accumulation [6] and [7]. The skeletal muscle mitochondria are particularly prone to ROS production [8]; an excessive generation leads to oxidative damages to DNA, proteins and lipids and to the consequent mitochondrial and cellular dysfunction [9] and [10]. At this point, cells must react in such a way that they can rescue damaged organelles, replacing them with newly formed ones (autophagy), or that they engage a programmed cellular death procedure (apoptosis). Apoptosis is the preferential way the cells use to suicide themselves avoiding the risk to damage surrounding 
cells; and this is what distinguishes apoptotic cell death from necrosis (in which a dying cell is not able to control its destruction and releases its content in the extracellular space, inducing injuries to the surrounding cells) [11] and [12]. Many compelling evidences have been produced about the likely involvement of apoptotic processes intervening during meat maturation [13] and [14].

Autophagy is a process designed to maintain homeostasis when it is threatened by starvation or oxidative injuries; it consists in a true self-digestion of potential toxic, unfolded or misfolded proteins and of entire organelles or portions of cytosol by means of the endosomal/lysosomal pathway [15]. The degree of oxidative stress determines the fate of the damaged cell; when injuries are too much pronounced, the protective autophagic self-digestion can result in autophagic death [16], that has distinguishable features compared to apoptosis regarding morphological, biomarkers and molecular standpoints [17], [18] and [19]. This two-face nature of autophagy constitutes a field of increasing controversy, because of its membership in both survival and death processes of cells [20]. The case of postmortem muscle is quite puzzling under this aspect, because it shows the physiologic conditions suitable to both the aforementioned answers. The sudden arrest of blood flow deprives muscle cells of oxygen and nutrients; it is demonstrated that starvation is the most effective mean to induce autophagic response [21] and [22]; moreover, some studies underline the presence and the physiological role of autophagy into muscle cells, for example in contexts such as ischemia/reperfusion injuries in cardiac myocytes [23], sarcopenia in elderly people [24] and, in relation to the skeletal muscle, in disease, aging, atrophy [25] and meat maturation [26]. However, meat scientists have considered mainly apoptosis as the working machinery intervening during muscle transformation, but in our opinion it is important to consider the possible role of autophagy because it could heavily affect the peculiarities of the ultimate meat product, particularly regarding tenderness. Considering the impaired mitochondrial respiration and the concomitant increase in ROS concentrations, the question about the duality apoptosis/autophagy in the process of muscle to meat conversion finds its 'raison d'etre': do the postmortem muscle cells counteract the oxidative stress activating autophagy, in an attempt to rescue the damaged structures, or do they directly fall into one of the programmed cell death forms? This survey is further complicated by many other factors influencing the development of muscle into meat, such as $\mathrm{pH}$, calcium concentration, sarcomere length and collagen content [4], age, gender, genotype, breed, nutritional status and levels of pre-slaughter stress (due to transportation and slaughter itself) [27] and [28]. The complex network originating from these aspects makes it difficult to build up a univocal and unambiguous underlying mechanism valid for any case of muscle to meat conversion.

In this work, we have focalized our attention on a particular kind of Italian meat, the Piedmontese. In a recent work [5] we have analyzed the Piedmontese meat from an omic standpoint, making use of metabolomics and 1D gel electrophoresis. With the present study, we want to deepen prolonged aged meat peculiarities from an omic point of view, using a time course project and monitoring eventual changes into the proteome of longissimus thoracis muscle. We used 2D electrophoresis techniques coupled with mass spectrometry spot identification, supported by metabolomic and phosphoproteomic analyses. Through this integrated omic approach, we have highlighted apoptosis as the principal mechanism involved in meat aging.

\section{Materials and methods}

Eight Piedmontese cull cows between 4 and 13 years old were raised in farms belonging to Consorzio La Granda (CN, Italy), located in Piedmont, then transported in about 20 min to a near slaughterhouse. The carcasses of the slaughtered animals were stored in a chilling room at $2{ }^{\circ} \mathrm{C}$, then transported to a meat processing plant on post-slaughter day 1. Longissimus thoracis muscles were removed and stored in a cooler at $1{ }^{\circ} \mathrm{C}$ (steady or dynamic), with a relative humidity of $78 \%$. A section of $10 \mathrm{~cm}$ was removed from all of the individual longissimus thoracis samples at days 0 , 
1, 10, 17 and 44 post-slaughter and used for all subsequent analyses. Liquid nitrogen was used to refrigerate each sample and to permit a fine grinding by means of mortar and pestle previously cleaned with acetone.

\subsection{Proteomics}

\subsubsection{Sample preparation}

Frozen samples of longissimus thoracis from 8 Piedmontese cows (approximately $5 \mathrm{mg}$ per sample) were crushed in a mortar containing liquid nitrogen. After grinding, the samples were incubated at $4{ }^{\circ} \mathrm{C}$ for $60 \mathrm{~min}$ in an extraction buffer containing $7 \mathrm{M}$ urea, $2 \mathrm{M}$ thiourea, $2 \%(\mathrm{w} / \mathrm{v})$ CHAPS, $40 \mathrm{mM}$ Tris, $0.1 \mathrm{mM}$ EDTA (pH 8.5), 2\% (v/v) protease inhibitor cocktail (Sigma-Aldrich, Basle, Switzerland), $2 \mathrm{mM}$ PMSF and $1 \mathrm{mM}$ DTT. Samples were centrifuged at 17,000 $\mathrm{g}$ for $20 \mathrm{~min}$ at $4{ }^{\circ} \mathrm{C}$ and the supernatants were collected [29]. The protein concentration of each group was determined using 2D Quant kit (GE Healthcare Life Sciences, UK) according to the manufacturer's instructions.

\subsubsection{D-PAGE}

2DE analyses on muscle samples were performed as previously reported [29]. $600 \mu \mathrm{g}$ of proteins was precipitated from a desired volume of each sample with a cold mix of tri-n-butyl phosphate/acetone/methanol (1:12:1). This solution is able to remove the lipid component. Before focusing, the proteins were reduced with $5 \mathrm{mM}$ tributylphosphine (TBP) and alkylated with $7.7 \mathrm{mM}$ iodoacetamide in a solution of $7 \mathrm{M}$ urea, $2 \mathrm{M}$ thiourea, $4 \%$ CHAPS, $40 \mathrm{mM}$ Tris and $0.1 \mathrm{mM}$ EDTA (pH 8.5). To prevent overalkylation, iodoacetamide excess was destroyed by adding equimolar amount of DTE. Seventeen centimeters IPG strips (Bio-Rad, CA, USA) pH 3-10 were rehydrated overnight with $330 \mu \mathrm{L}$ of rehydratation solution containing $7 \mathrm{M}$ urea, $2 \mathrm{M}$ thiourea, $4 \%$ (w/v) CHAPS and 0.5\% (w/v) pH 3-10 carrier ampholyte (Bio-lyte; Bio-Rad, CA, USA) and $100 \mu \mathrm{L}$ of sample was loaded using the cup-loading method. The total product time per voltage applied was $80,000 \mathrm{~V}$ for each strip at $20^{\circ} \mathrm{C}$. After IEF, the IPG gel strips were incubated at room temperature for $30 \mathrm{~min}$ in $6 \mathrm{M}$ urea, $30 \% \mathrm{w} / \mathrm{v}$ glycerol, $2 \% \mathrm{w} / \mathrm{v}$ SDS, $5 \mathrm{mM}$ Tris- $\mathrm{HCl}$ and $\mathrm{pH} 8.8$. The strips were sealed at the top of a $1.5 \mathrm{~mm}$ vertical second dimensional gel with $0.5 \%$ agarose in $25 \mathrm{mM}$ Tris, $192 \mathrm{mM}$ glycine, 0.1\% SDS and pH 8.3. SDS-PAGE was carried out on homogeneous running gels $12 \% \mathrm{~T}$ and $2.6 \% \mathrm{C}$. Running conditions were $40 \mathrm{~mA} / \mathrm{gel}$ until the bromophenol blue reached the bottom of the gel. Protein spots were stained by sensitive Coomassie brilliant blue G250 stain. Three technical replicates per sample were performed.

\subsubsection{Image analysis}

120 stained gels ( 8 biological replicates $\times 5$ storage points $\times 3$ technical replicates) were digitalized using an ImageScanner and LabScan software 3.01 (Bio-Rad Hercules, CA). The 2-DE image analysis was carried out and spots were detected and quantified using the Progenesis SameSpots software version 2.0 (Nonlinear Dynamics, New Castle, UK).For each protein spot, the average spot quantity value and its variance coefficient in each group were determined. One-way analysis of variance (ANOVA) was carried out at $\mathrm{p}<0.05$ to assess for absolute protein changes among day 0 and the other time points. The statistically significant spots with fold $\geq 1.5$ were cut and subjected to in-gel trypsin digestion [30].

\subsubsection{LC-ESI-CID-MS/MS}


Samples were analyzed using a split-free nano-flow liquid chromatography system (EASY-nLC II, Proxeon, Odense, Denmark) coupled to a 3D-ion trap (model AmaZon ETD, Bruker Daltonik, Germany) equipped with an online ESI nano-sprayer (the spray capillary was a fused silica capillary, $0.090 \mathrm{~mm}$ O.D., $0.020 \mathrm{~mm}$ I.D.). For all experiments a sample volume of $15 \mu \mathrm{L}$ was loaded by the autosampler onto a homemade $2 \mathrm{~cm}$ fused silica precolumn (100 $\mu \mathrm{m}$ I.D.; $375 \mu \mathrm{m}$ O.D.; Reprosil C18-AQ, $5 \mu \mathrm{m}$, Dr. Maisch GmbH, Ammerbuch-Entringen, Germany). Sequential elution of peptides was accomplished using a flow rate of $300 \mathrm{~nL} / \mathrm{min}$ and a linear gradient from Solution A (2\% acetonitrile; $0.1 \%$ formic acid) to $50 \%$ of Solution B (98\% acetonitrile; $0.1 \%$ formic acid) in $40 \mathrm{~min}$ over the precolumn on-line with a homemade $15 \mathrm{~cm}$ resolving column (75 $\mu \mathrm{m}$ I.D.; $375 \mu \mathrm{m}$ O.D.; Reprosil C18-AQ, $3 \mu \mathrm{m}$, Dr. Maisch GmbH, Ammerbuch-Entringen, Germany). The acquisition parameters for the mass spectrometer were as follows: dry gas temperature, $220{ }^{\circ} \mathrm{C}$; dry gas, $4.0 \mathrm{~L} / \mathrm{min}$; nebulizer gas, $10 \mathrm{psi}$; electrospray voltage, $4000 \mathrm{~V}$; highvoltage end-plate offset, $-200 \mathrm{~V}$; capillary exit, $140 \mathrm{~V}$; trap drive: 63.2 ; funnel 1 in. $100 \mathrm{~V}$ out of $35 \mathrm{~V}$ and funnel 2 in. $12 \mathrm{~V}$ out of $10 \mathrm{~V}$; ICC target, 200,000 and maximum accumulation time, $50 \mathrm{~ms}$. The sample was measured with the Enhanced Resolution Mode at $8100 \mathrm{~m} / \mathrm{z}$ per second (which allows monoisotopic resolution up to four charge stages), positive polarity, scan range from $\mathrm{m} / \mathrm{z} 300$ to 1500,5 spectra averaged, and rolling average of 1. The "Smart Decomposition" was set to "auto". Acquired CID spectra were processed in DataAnalysis 4.0, and deconvoluted spectra were further analyzed with BioTools 3.2 software and submitted to Mascot search program (inhouse version 2.2, Matrix Science, London, UK). The following parameters were adopted for database searches: NCBInr database (release date 22/09/2012; 20,543,454 sequences; $7,050,788,919$ residues); taxonomy $=$ all entries; peptide and fragment mass tolerance of $\pm 0.3 \mathrm{Da}$; enzyme specificity trypsin with 2 missed cleavages considered; fixed modifications: carbamidomethyl $(\mathrm{C})$ and variable modifications: oxidation $(\mathrm{M})$.

\subsection{Immunoblotting}

$20 \mu \mathrm{g}$ of proteins was dissolved in sample buffer composed by $12 \%$ (w/v) sucrose, $4 \mathrm{M}$ urea, $50 \mathrm{mM}$ Tris- $\mathrm{HCl}, 4 \%$ (w/v) SDS, $200 \mathrm{mM}$ DTT and $0.01 \%(\mathrm{w} / \mathrm{v})$ bromophenol blue and loaded on a $12 \%$ acrylamide gel. Gel run at $100-120 \mathrm{~V}$ for $2 \mathrm{~h}$. 1D gels were transferred to nitrocellulose filters for immunoblot analysis and probed with anti-phophoserine/threonine antibody (1:1500) (612548, BD Transduction Laboratories). Goat anti-mouse secondary antibody (IgG1-HRP, sc2060) was from Santa Cruz Biotechnology (CA, USA). ECL-Plus (GE Healthcare, UK) was used as revealing system. The bands recognized by antibody were cut, trypsin digested [38] and identified by nano-HPLC-MS/MS.

\subsection{1. $\mathrm{TiO}_{2}$ enrichment and $\mathrm{ETD}$ and neutral loss analysis}

Purification of phosphopeptides was then performed according to Thingholm et al. [31]. The $\mathrm{TiO}_{2^{-}}$ enriched samples were analyzed using a split-free nano-flow liquid chromatography (LC) system (EASY-nLC II, Thermo Fisher Scientific) coupled to a 3D-ion trap (model AmaZon ETD, Bruker Daltonics) equipped with an online ESI nano-sprayer (the spray capillary was a fused silica capillary, $90 \mu \mathrm{m}$ O.D., $20 \mu \mathrm{m}$ I.D.) working in positive ion mode. To identify phosphorylation sites, two types of peptide fragmentation were carried out in parallel in the mass spectrometer: (i) collision induced dissociation (CID) and (ii) electron transfer dissociation (ETD). When CID was used a MS2 was automatically performed on the three most intense MS ions, and MS3 was triggered if one of the top three MS2 peaks corresponded with neutral loss (NL) of 98.0, 49.0 and $32.7 \mathrm{~m} / \mathrm{z}$. A detailed description of the used LC-MS/MS conditions was given previously [32]. Results are summarized in Table 3.

\subsection{Metabolomics}


Metabolomic analysis has been carried on as previously reported, with minor modifications [5] and [33]. Metabolites were extracted from $50 \mathrm{mg}$ of each sample, by means of $500 \mu \mathrm{L}$ solution of 50:30:20 of ice-cold methanol:acetonitrile:bidistilled water; samples were vortexed in a thermomixer for $30 \mathrm{~min}$ at $4{ }^{\circ} \mathrm{C}$, then centrifuged at $13,500 \mathrm{~g}$ for $15 \mathrm{~min}$ at $4{ }^{\circ} \mathrm{C}$. The supernatants, containing the extracted metabolites, were used for the analysis, while the bottom residues discarded. Samples were thus loaded onto a rapid resolution HPLC system (LC Packings, DIONEX, Sunnyvale, USA) as to perform chromatographic separation of hydrophilic metabolites. The system featured a binary pump and vacuum degasser, well-plate autosampler with a six-port micro-switching valve and a thermostated column compartment. A Phenomenex Luna $3 \mu \mathrm{m}$ HILIC $200 \mathrm{~A}(150 \times 2.0 \mathrm{~mm})$, protected by a guard column HILIC $4 \times 2.0 \mathrm{~mm}$ ID (Phenomenex) was used to perform metabolite separation over a phase $\mathrm{B}(100 \%$ acetonitrile $+10 \mathrm{mM}$ ammonium acetate) to phase A (double distilled $18 \mathrm{~m} \Omega$ water, $+10 \mathrm{mM}$ ammonium acetate) gradient lasting $35 \mathrm{~min}$. In details, we set the following LC parameters: injection volume, $20 \mu \mathrm{L}$; column temperature, $25{ }^{\circ} \mathrm{C}$; and flow rate of $0.3 \mathrm{~mL} / \mathrm{min}$. The multistep gradient was set as follows: $0-5 \mathrm{~min} 100 \% \mathrm{~B}$; 5$15 \mathrm{~min}$, from $100 \% \mathrm{~B}$ to $70 \% \mathrm{~B} ; 15-20 \mathrm{~min}$, from $70 \% \mathrm{~B}$ to $50 \% \mathrm{~B} ; 20-25 \mathrm{~min}$, from $50 \%$ B to $0 \%$ $\mathrm{B}$; 25-30 min, isocratic at $0 \% \mathrm{~B} ; 30-30.1 \mathrm{~min}$, return to the initial conditions $100 \% \mathrm{~B}$; and $30.1-$ $35 \mathrm{~min}$, isocratic column equilibration at $100 \% \mathrm{~B}$. The eluate from the HPLC system was linked online with a Micro Q-Tof Bruker Daltonics mass spectrometer equipped with an ESI ion source. Instrument calibration was performed externally everyday with a sodium formate solution consisting of $10 \mathrm{mM}$ sodium hydroxide in $50 \%$ isopropanol:water and $0.1 \%$ formic acid. External mass scale calibration was performed twice a day through direct automated injection of the calibration solution by a 6-port divert-valve. Mass spectrometer runs were exported into mzXML files and analyzed through the software MAVEN [34] for correct metabolite assignment, on the basis of absolute intact mass (within a $10 \mathrm{ppm}$ window) against the KEGG database [35], and expected retention times on the basis of metabolite chemical properties. The outcoming time course trends for each metabolite of interest result from the analysis of 24 replicates ( 3 technical for each of the 8 biological).

\section{Results and discussion}

This is an 'omic' study based on a time course analysis of meat samples from longissimus thoracis muscles of 8 different bovines of Piedmontese breed. The time points of sample collection were 0 , $1,10,17$ and 44 days from the moment of slaughtering, with the aim of analyzing biochemical changes into the aging meat, especially giving a first glance to eventual connections of our results with the duality apoptosis/autophagy. The proteomic analysis is based on classical 2D gel electrophoresis, able to separate proteins by their isoelectric point and molecular weight (Fig. 1). We have opted for 2D technique because of its better resolving power over the 1D technique, used in our previous work [5]; we carried out quantitative comparisons between the 0-day proteome and the proteomes extracted from the other time course points 1, 10, 17 and 44, and the results are summarized in Table 1, in which we have reported the spots appeared to be differential at least in one of the four time point comparisons (with a fold change >1.5). The differential spots were identified as the known protein by MASCOT database searching; the validation of the identifications was carried on taking into account the number of peptide matching against the candidate protein and the coverage of its amino acidic sequence by these peptides. There are 44 differential spots, but there is not a correspondence with the factual number of differential proteins, which are a total of 26. Indeed, some identified proteins are redundant and are repeated at least in two different spots. 

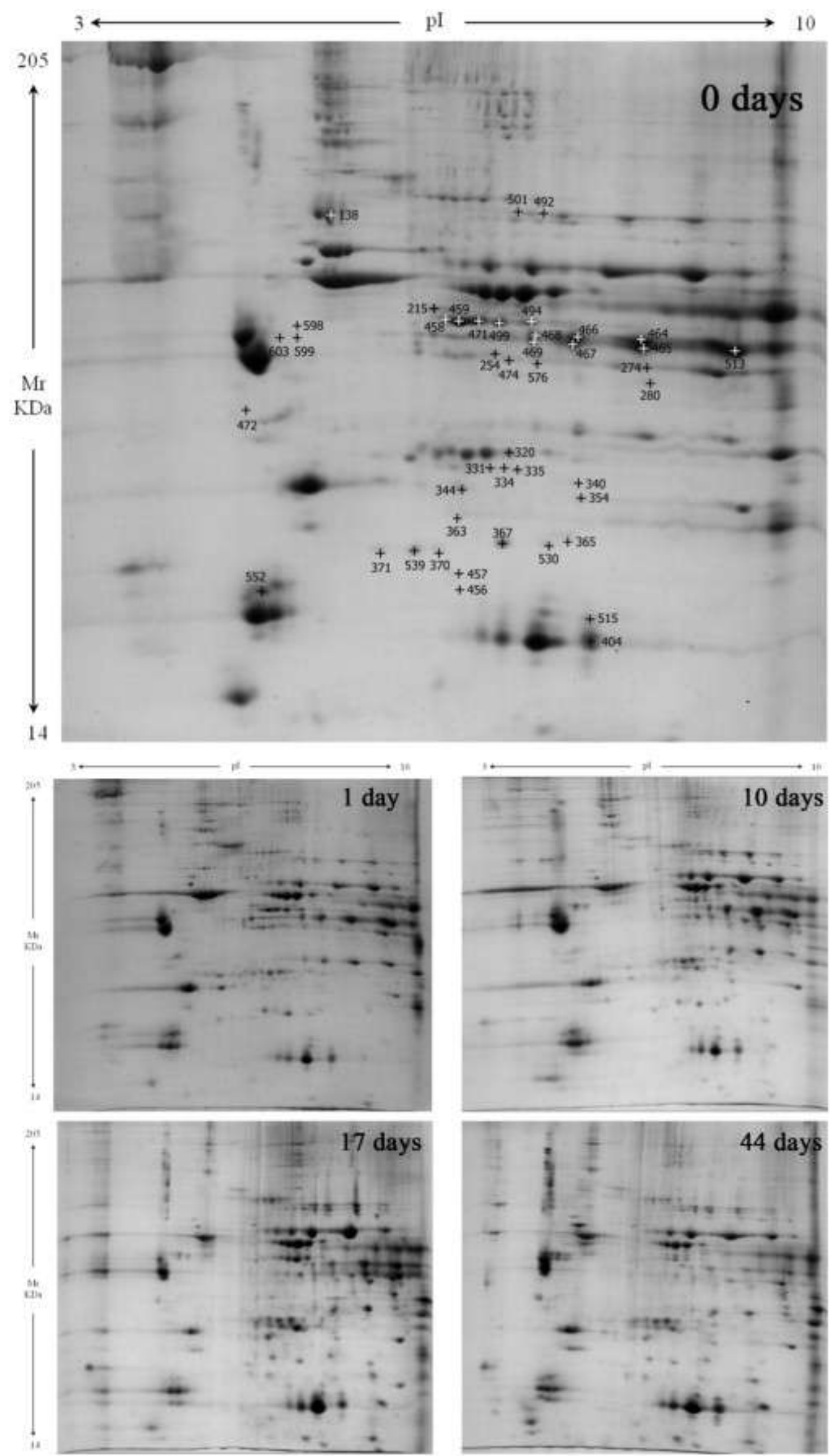

Fig. 1. 
Example results of 2D gel analysis for every time point $(0,1,10,17,44$ days). On the bigger one, the numbers indicate the spots showing a differential intensity at least in one of the 1 , 10,17 and 44 days against day 0.

Figure options

Table 1.

Differential proteins as gleaned from 2DE analyses of longissimus dorsi muscles at postmortem days $0,1,10,17$ and 44 .

\begin{tabular}{|c|c|c|c|c|c|c|c|c|c|c|c|c|}
\hline \begin{tabular}{|l|}
$\begin{array}{l}\text { No. } \\
\text { of } \\
\text { spot }\end{array}$ \\
\end{tabular} & $\begin{array}{l}\text { MW } \\
\text { KDa }\end{array}$ & pI & Matches $^{\mathrm{a}}$ & \begin{tabular}{|l|}
$\begin{array}{l}\text { No. of } \\
\text { peptides } \\
\text { identified }^{\mathrm{a}}\end{array}$ \\
\end{tabular} & $\begin{array}{l}\text { Mascot } \\
\text { score }\end{array}$ & $\begin{array}{l}\text { Sequence } \\
\text { coverage }\end{array}$ & $\begin{array}{l}\text { NCBI } \\
\text { accession } \\
\text { no. }\end{array}$ & Protein ID (Bos taurus) & \begin{tabular}{|l|} 
o day \\
vs \\
1 day \\
\end{tabular} & \begin{tabular}{|l|}
0 day \\
vs \\
10 days \\
\end{tabular} & \begin{tabular}{|l|}
0 day \\
vs \\
17 days
\end{tabular} & $\begin{array}{l}\text { O day } \\
44 \text { days }\end{array}$ \\
\hline 138 & 42,187 & $\mid 5.30$ & $49(13)$ & 8 (3) & 483 & $18 \%$ & $\mid$ gi|741897519 & Beta-actin-protein-like 2 & $=$ & \begin{tabular}{|l|}
2.5 \\
down
\end{tabular} & $\begin{array}{l}2.1 \\
\text { down }\end{array}$ & 2.1 down \\
\hline 215 & 20,301 & 6.38 & $8(2)$ & $\| 2(1)$ & 109 & $14 \%$ & $\mid$ gi|296491201 & \begin{tabular}{|l|} 
Glyceraldehyde-3- \\
phosphate dehydrogenase- \\
like
\end{tabular} & $=$ & $=$ & | 2.4 & 2.4 down \\
\hline 254 & 38,236 & |6.42 & $4(2)$ & | $2(1)$ & 83 & $\mid 5 \%$ & gi|78365297 & \begin{tabular}{|l|} 
Glycerol-3-phosphate \\
dehydrogenase $[\mathrm{NAD}(+)]$, \\
cytoplasmic
\end{tabular} & $=$ & $=$ & $=$ & 1.9 down \\
\hline 274 & 36,916 & $\mid 8.12$ & $68(22)$ & ||22(8) & 954 & $52 \%$ & gi|27806559 & \begin{tabular}{|l|} 
1-Lactate dehydrogenase A \\
chain
\end{tabular} & $=$ & 1.5 up & 1.6 up & 1.5 down \\
\hline 280 & 35,903 & 8.17 & $17(5)$ & $8(3)$ & 367 & $21 \%$ & gi|217590 & Lactate dehydrogenase-A & $=$ & $=$ & $=$ & 1.8 down \\
\hline 367 & 20,024 & 6.76 & $52(8)$ & $14(4)$ & 595 & $50 \%$ & gi|27805849 & Alpha-crystallin B chain & $=$ & $=$ & $=$ & 1.5 down \\
\hline 370 & 17,515 & $\mid 5.95$ & $9(1)$ & | $3(1)$ & 124 & $17 \%$ & $\mid$ gi|115496724 & Heat shock protein beta- 6 & $=$ & $\begin{array}{l}1.7 \\
\text { down }\end{array}$ & $\begin{array}{l}1.5 \\
\text { down }\end{array}$ & 2.1 down \\
\hline 371 & 17,515 & $\mid 5.95$ & $6(1)$ & 3 $3(1)$ & 86 & $21 \%$ & $\mid$ gi|115496724 & Heat shock protein beta- 6 & $\begin{array}{l}1.8 \\
\text { down }\end{array}$ & $\begin{array}{l}1.7 \\
\text { down }\end{array}$ & $\begin{array}{l}1.8 \\
\text { down }\end{array}$ & 1.9 down \\
\hline 458 & 29,800 & $\mid 7.74$ & $60(13)$ & $\mid 15(6)$ & 679 & $40 \%$ & gi|47824864 & $\begin{array}{l}\text { Troponin } \mathrm{T} \text {, fast skeletal } \\
\text { muscle }\end{array}$ & $=$ & $=$ & $\begin{array}{l}2.4 \\
\text { down }\end{array}$ & 4.3 down \\
\hline 459 & 29,800 & $\mid 7.74$ & |124(40) & || $17(9)$ & 943 & $36 \%$ & $\mid$ gi|47824864 & $\begin{array}{l}\text { Troponin } \mathrm{T} \text {, fast skeletal } \\
\text { muscle }\end{array}$ & $=$ & $=$ & $\begin{array}{l}2.3 \\
\text { down }\end{array}$ & 7.2 down \\
\hline 464 & 39,925 & $\mid 8.45$ & $9(3)$ & |6 $6(2)$ & 256 & $22 \%$ & $\mid$ gi|156120479 & $\begin{array}{l}\text { Fructose-bisphosphate } \\
\text { aldolase A }\end{array}$ & $=$ & $=$ & $=$ & 2.2 down \\
\hline 465 & 36,073 & $\mid 8.50$ & $109(22)$ & |20 (6) & 806 & $59 \%$ & gi|77404273 & \begin{tabular}{|l}
$\begin{array}{l}\text { Glyceraldehyde-3- } \\
\text { phosphate dehydrogenase }\end{array}$ \\
\end{tabular} & $=$ & $=$ & $=$ & 2.1 down \\
\hline 466 & 29,800 & || 7.74 & $43(13)$ & $\mid 11(6)$ & 585 & $35 \%$ & $\mid$ gi|47824864 & $\begin{array}{l}\text { Troponin } \mathrm{T} \text {, fast skeletal } \\
\text { muscle }\end{array}$ & $=$ & $=$ & $=$ & 1.7 down \\
\hline 467 & 36,073 & 8.50 & $102(24)$ & $\mid 15(6)$ & 768 & $41 \%$ & gi|77404273 & \begin{tabular}{|l}
$\begin{array}{l}\text { Glyceraldehyde-3- } \\
\text { phosphate dehydrogenase }\end{array}$ \\
\end{tabular} & $=$ & $=$ & $=$ & 2.0 down \\
\hline 468 & 36,073 & $\mid 8.50$ & $63(7)$ & $\mid 14(4)$ & 665 & $41 \%$ & gi|77404273 & \begin{tabular}{|l}
$\begin{array}{l}\text { Glyceraldehyde-3- } \\
\text { phosphate dehydrogenase }\end{array}$ \\
\end{tabular} & $=$ & $=$ & $=$ & 2.6 down \\
\hline 469 & 36,073 & 8.50 & $79(16)$ & $\mid 16(5)$ & 698 & $43 \%$ & gi|77404273 & \begin{tabular}{|l}
$\begin{array}{l}\text { Glyceraldehyde-3- } \\
\text { phosphate dehydrogenase }\end{array}$ \\
\end{tabular} & $=$ & $=$ & $\begin{array}{l}1.5 \\
\text { down }\end{array}$ & 2.3 down \\
\hline 471 & 29,800 & $\mid 7.74$ & $90(26)$ & |15 (7) & 747 & $33 \%$ & $\mid$ gi|47824864 & \begin{tabular}{|l} 
Troponin $\mathrm{T}$, fast skeletal \\
muscle
\end{tabular} & $=$ & $=$ & $=$ & 3.5 down \\
\hline 472 & 42,451 & $\mid 5.31$ & $3(1)$ & 2(1) & 52 & $7 \%$ & |gi|27819614 & $\begin{array}{|lll|}\begin{array}{l}\text { Actin, alpha } \\
\text { muscle }\end{array} & \text { skeletal } \\
\end{array}$ & $=$ & $=$ & 2.6 up & 3.6 up \\
\hline 474 & 38,873 & 6.92 & $5(2)$ & $2(2)$ & 111 & $6 \%$ & gi|27807289 & Annexin A2 & $=$ & $1.5 \mathrm{up}$ & $1.5 \mathrm{up}$ & $=$ \\
\hline 494 & 43,190 & |6.63 & $45(15)$ & || $18(7)$ & 812 & $44 \%$ & |gi|60097925 & Creatine kinase M-type & $=$ & $=$ & $\begin{array}{l}1.5 \\
\text { down }\end{array}$ & 2.3 down \\
\hline 499 & 43,190 & 6.63 & $38(18)$ & $14(8)$ & 837 & $40 \%$ & gi|60097925 & Creatine kinase M-type & $=$ & $=$ & $=$ & 2.0 down \\
\hline 513 & 36,073 & $\mid 8.50$ & 128(30) & $\mid 17(8)$ & 796 & $47 \%$ & gi|77404273 & \begin{tabular}{|l}
$\begin{array}{l}\text { Glyceraldehyde-3- } \\
\text { phosphate dehydrogenase }\end{array}$ \\
\end{tabular} & $=$ & $=$ & $=$ & 1.5 down \\
\hline 530 & 20,024 & 6.76 & $15(4)$ & $6(1)$ & 330 & $30 \%$ & gi|27805849 & Alpha-crystallin B chain & $=$ & $=$ & 1.8 & $=$ \\
\hline
\end{tabular}




\begin{tabular}{|c|c|c|c|c|c|c|c|c|c|c|c|c|}
\hline \begin{tabular}{|l|} 
No. \\
of \\
spot
\end{tabular} & $\begin{array}{l}\text { MW } \\
\text { kDa }\end{array}$ & pI & Matches $^{\mathrm{a}}$ & \begin{tabular}{|l|} 
No. of \\
peptides \\
identified $^{\mathrm{a}}$
\end{tabular} & $\begin{array}{l}\text { Mascot } \\
\text { score }\end{array}$ & $\begin{array}{l}\text { Sequence } \\
\text { coverage }\end{array}$ & $\begin{array}{l}\text { NCBI } \\
\text { accession } \\
\text { no. }\end{array}$ & Protein ID (Bos taurus) & \begin{tabular}{|l|} 
day \\
vs \\
1 day
\end{tabular} & \begin{tabular}{|l|}
0 day \\
vs \\
10 days
\end{tabular} & \begin{tabular}{|l|}
0 day \\
vs \\
17 days
\end{tabular} & $\begin{array}{l}0 \text { day } \\
44 \text { days }\end{array}$ \\
\hline & & & & & & & & & & & down & \\
\hline 539 & 17,525 & 5.95 & $42(1)$ & $6(1)$ & 237 & $37 \%$ & $\mid$ gi|119224088 & $\begin{array}{l}\text { Heat shock protein, alpha- } \\
\text { crystallin-related, B6 }\end{array}$ & $=$ & = & $\begin{array}{l}2.2 \\
\text { down }\end{array}$ & 2.0 down \\
\hline 552 & 19,114 & 4.91 & $24(7)$ & 9(4) & 432 & $54 \%$ & $\mid$ gi|115497166 & $\begin{array}{l}\text { Myosin regulatory light } \\
\text { chain 2, skeletal muscle } \\
\text { isoform }\end{array}$ & $=$ & $=$ & | 1.6 & $=$ \\
\hline 576 & 35,903 & 8.17 & $53(19)$ & $19(9)$ & 875 & $46 \%$ & gi|217590 & Lactate dehydrogenase-A & $=$ & $=$ & $=$ & 1.5 down \\
\hline 320 & 26,901 & 6.45 & $62(29)$ & $17(11)$ & 1104 & $78 \%$ & gi|61888856 & Triosephosphate isomerase & $=$ & $=$ & 1.5 up & $=$ \\
\hline 331 & 26,901 & 6.45 & $94(41)$ & $18(11)$ & 1157 & $79 \%$ & gi|61888856 & Triosephosphate isomerase & $=$ & $=$ & 1.8 up & 1.5 up \\
\hline 334 & 43,190 & 6.63 & $100(24)$ & $19(5)$ & 861 & $34 \%$ & gi|60097925 & Creatine kinase M-type & $=$ & 2.3 up & 3.7 up & 3.1 up \\
\hline 335 & 43,190 & 6.63 & $75(15)$ & $20(4)$ & 719 & $34 \%$ & gi|60097925 & Creatine kinase M-type & $=$ & 1.8 up & 3.4 up & 2.1 up \\
\hline 340 & 23,826 & 6.89 & $29(16)$ & $8(7)$ & 555 & $44 \%$ & $\mid$ gi|29135329 & $\begin{array}{|ll|}\begin{array}{l}\text { Glutathione } \\
\mathrm{P}\end{array} & \text { S-transferase } \\
\end{array}$ & $=$ & $=$ & 1.7 up & 2.0 up \\
\hline 344 & 20,194 & 6.84 & $42(14)$ & $15(8)$ & 718 & $60 \%$ & gi|62751849 & Protein DJ-1 & $=$ & 1.5 up & 1.9 up & $2.1 \mathrm{up}$ \\
\hline 354 & 27,525 & 7.59 & $67(16)$ & ||17 (9) & 793 & $74 \%$ & gi|61888850 & \begin{tabular}{|l|l|} 
Adenylate & kinase \\
isoenzyme 1 isoform X1
\end{tabular} & $=$ & $=$ & $=$ & 1.5 up \\
\hline 363 & 20,024 & 6.76 & $45(5)$ & |12(2) & 466 & $49 \%$ & gi|27805849 & Alpha-crystallin B chain & $\begin{array}{l}2.7 \\
\text { up }\end{array}$ & 3.2 up & 3.0 up & 2.2 up \\
\hline 365 & 21,106 & 7.72 & $24(12)$ & $8(4)$ & 484 & $45 \%$ & $\mid$ gi|75812940 & \begin{tabular}{|l|} 
Phosphatidylethanolamine- \\
binding protein 1
\end{tabular} & $=$ & $=$ & 1.6 up & 1.7 up \\
\hline 404 & 17,067 & 6.90 & $81(24)$ & $\mid 13(8)$ & 745 & $73 \%$ & gi|27806939 & Myoglobin & $=$ & $=$ & $\begin{array}{l}.5 \\
\text { down }\end{array}$ & $=$ \\
\hline 456 & 20,024 & 6.76 & $18(4)$ & $6(2)$ & 324 & $29 \%$ & gi|27805849 & Alpha-crystallin B chain & $=$ & $=$ & 1.5 up & 1.9 up \\
\hline 457 & $3,741,526$ & 6.07 & $11(3)$ & $5(2)$ & 200 & $0 \%$ & gi|296490722 & Titin & $=$ & 1.7 up & $2.5 \mathrm{up}$ & 3.3 up \\
\hline 492 & 58,536 & 7.62 & $35(10)$ & $\mid 14(8)$ & 680 & $25 \%$ & $\mid$ gi|528961976 & $\begin{array}{|ll|}\begin{array}{l}\text { Pyruvate kinase } \\
\text { isoform } \mathrm{X} 1\end{array} & \\
\end{array}$ & $=$ & 1.6 up & 1.5 up & 1.9 up \\
\hline 501 & 58,536 & 7.98 & $72(14)$ & |21 (10) & 1025 & $40 \%$ & $\mid$ gi|528961976 & \begin{tabular}{|l|}
$\begin{array}{l}\text { Pyruvate kinase PKM } \\
\text { isoform X1 }\end{array}$ \\
\end{tabular} & $=$ & 1.8 up & 1.8 up & 2.2 up \\
\hline 598 & 19,114 & 4.91 & $74(22)$ & $\mid 17(8)$ & 801 & $82 \%$ & $\mid$ gi|115497166 & $\begin{array}{l}\text { Myosin regulatory light } \\
\text { chain 2, skeletal muscle } \\
\text { isoform }\end{array}$ & $\begin{array}{l}1.8 \\
\text { up }\end{array}$ & $=$ & 2.2 up & 2.6 up \\
\hline 599 & 19,114 & 4.91 & $34(11)$ & |12(4) & 486 & $52 \%$ & gi|28372499 & \begin{tabular}{|l} 
Myosin regulatory light \\
chain 2, skeletal muscle \\
isoform
\end{tabular} & $=$ & 2.0 up & $=$ & 3.6 up \\
\hline 603 & 19,114 & 4.91 & $80(25)$ & $\mid 15(8)$ & 816 & $62 \%$ & $\mid$ gi|115497166 & $\begin{array}{l}\text { Myosin regulatory light } \\
\text { chain 2, skeletal muscle } \\
\text { isoform }\end{array}$ & $=$ & $=$ & |l 1.8 & $2.1 \mathrm{up}$ \\
\hline
\end{tabular}

a Values between brackets indicate statistically significant peptides $(\mathrm{p}<0.05)$.

\subsection{Proteolysis}

The proteome changes during the muscle-to-meat conversion process are radical; many studies have been finalized to shed light on these variations [36], [37], [38], [39] and [40], and many others demonstrated the process of muscle proteolysis as the hub of muscle evolution into meat [41], [42] and [43]; our 2D results are in agreement with previous findings, as stated by variations in differential spots containing structural proteins: spots 458, 459, 466 and 471 are identified as troponin $\mathrm{T}$. The time course trend indicates that an important downregulation of troponin $\mathrm{T}$ of longissimus thoracis Piedmontese muscle begins to appear from day 17 onward, to reach its top at day 44 (4.3 fold change for spot 458; 7.2 fold change for spot 459, Table 1); this experimental result rewards the 44 days-aged meat, because, as it has been previously reported [38] and [44], degradation of troponin $\mathrm{T}$ is known to be a descriptive indicator of meat tenderization process. Another component of muscular architecture, actin, clearly describes the ongoing proteolysis during 
the aging period; later in our discussion we will recall the upward trend of a particular actin fragment $(31 \mathrm{kDa})$ linked with apoptosis. The progressive disruption of muscle architecture is also stated by the time course trend of myosin light chain 2, one of the constituent subunits of myosin: looking at spot 552, we can unequivocally deduce the presence of this protein, due to the similarity of the MW of the spot (about $21 \mathrm{kDa}$ ) with the expected MW for myosin light chain $2(19 \mathrm{kDa})$; the 1.6 down fold-change appears at day 17. Table 1 shows the presence of myosin light chain 2 also in spots 598, 599 and 603, that could seem quite puzzling referring to the observed MW (about $45 \mathrm{kDa})$, much higher than the expected $(19 \mathrm{kDa})$; this fact can only be explained by the formation of proteic aggregates due to the presence of ROS, as previously demonstrated in thylakoid membranes [45]. Another hint to the proteolytic alterations suffered by muscle cells comes from the downward trend of beta-actin-like protein 2 (MW $66 \mathrm{kDa}$ ), a known ubiquitary component of the cytoskeleton and a mediator of internal cell mobility. Finally, the last observation is about the upward trend of spot 457, identified as titin, but representing a fragmented species (as we can deduce reminding the MW of the entire protein, nearly $4 \mathrm{MDa}$ ); its increase certifies once more the ongoing proteolysis.

\subsection{Energetic evolution}

Paying attention to the muscle metabolic behavior, we can note from Table 1 that $2 \mathrm{D}$ gel comparisons show a progressive dysregulation of the principal 'reloading' mechanism of muscle fibers, as stated by the downward trend of creatine kinase M-type (observed MW coincident to the expected, $43 \mathrm{kDa}$, in spots 494 and 499) and by the upward trend of spots 334 and 335, identified as creatine kinase M-type, but containing only its fragmented species (about $29 \mathrm{kDa}$ ). This is one key enzyme in the correct functioning of the so-called creatine-phosphocreatine shuttle: it reconverts myofibrillar ATP from ADP thanks to the inorganic phosphate group provided by the high-energy compound phosphocreatine, which is synthesized by mitochondrial creatine kinase from creatine and the ATP coming from oxidative phosphorylation [46]; the sudden $\mathrm{O}_{2}$ shortages impair ATP production by electron transport chain, so the lack of great quantities of ATP induces phosphocreatine shuttle impairment, as stated by the decreasing levels of creatine kinase $\mathrm{M}$ and by the metabolomic relative quantification of the phosphocreatine levels (progressively decreasing); as we explained, phosphocreatine quantities depend on the availability of ATP, and the metabolomic results for ATP are in agreement with phosphocreatine and creatine kinase M trends (Fig. 2). 


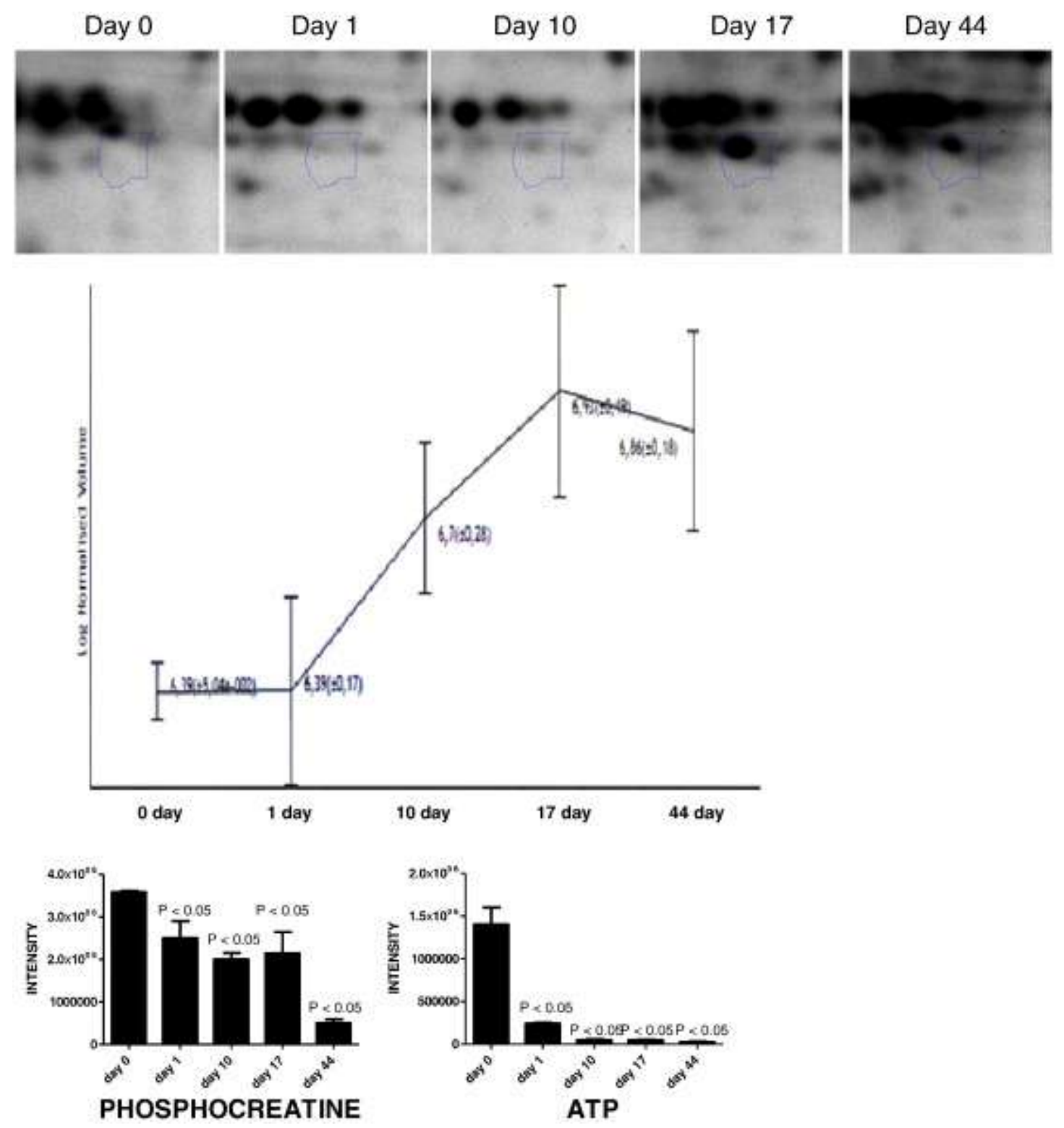

Fig. 2. Spot 334 on gels and its graphical trend (creatine kinase fragment), with the intensity values as means \pm SD reported for each time point. Metabolomic results for creatine kinase shuttle (considering ATP and phosphocreatine) presented as mean \pm SEM; the statistically significant variations evidenced with $\mathrm{p}<0.05$ refer to day 0 against each other.

The muscles try to counteract the progressive depletion of energetic molecules relying on glycolysis; in physiological conditions, with abundance of $\mathrm{O}_{2}$, its endproduct is pyruvate, oxidized through the Krebs cycle; nevertheless, the absence of $\mathrm{O}_{2}$ hampers the electron transfer from NADH and FADH2 to obtain NAD + and FAD useful to the Krebs reactions. So, the slaughtered muscle makes use of the lactic fermentation to exhaust the accumulating pyruvate, reducing it thanks to NADH electrons. The result is a progressive increase in lactate, with a steady state reached between days 17 and 44 (Fig. 3); the concomitant upregulation of lactate dehydrogenase A chain between days 10 and 17 (spot 274) is explainable as to cope with increasing levels of pyruvate to be reducted to lactate; the following fall at 44 days is in agreement with lactate steady state (Fig. 3, Table 1). In the context of glycolysis, we can note the upregulation of two isoforms of pyruvate kinase from day 10 onward: this enzyme catalyzes one of the ATP-producing glycolytic reactions, and we can hypothesize that the upregulation indicates the cellular attempt to maintain an adequate level of ATP; however, these data are in contrast with the downward trend at 44 days of two other 
glycolytic enzymes, fructose biphosphate aldolase A and glyceraldehyde phosphate dehydrogenase, as to indicate the likely consumption of glycolytic intermediates.

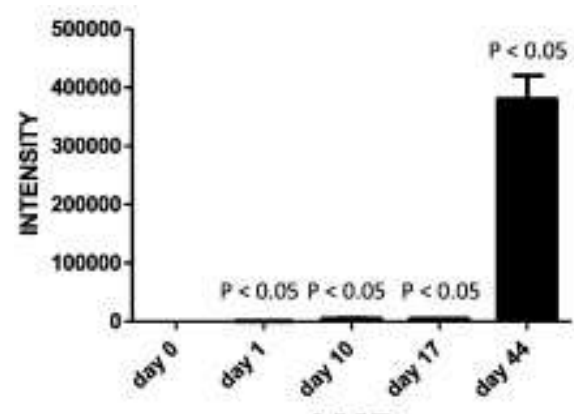

AMP

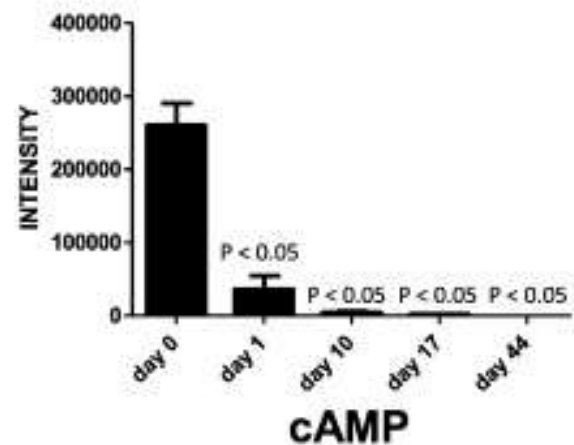

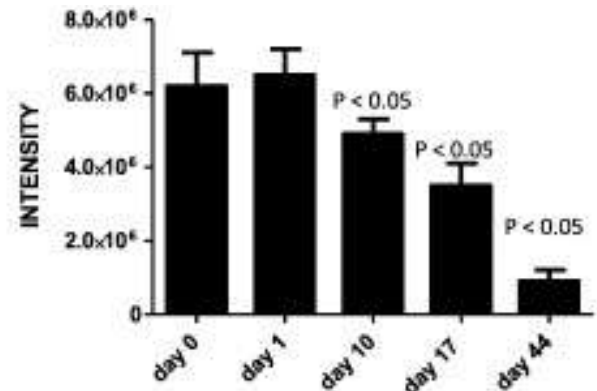

GSH

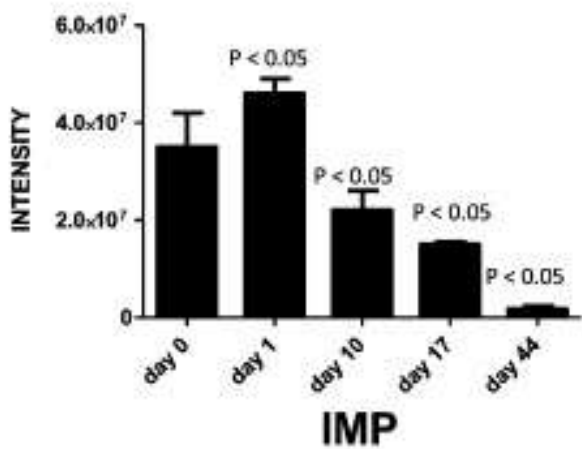



GSSG

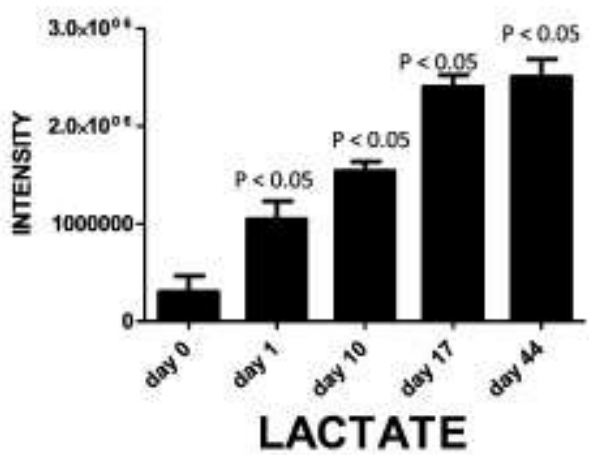

Fig. 3. Time course trend for some selected key metabolites; results are reported as mean \pm SEM; the statistically significant variations evidenced with $\mathrm{p}<0.05$ refer to day 0 against each other.

The 2D time course study of muscle to meat conversion confirms the importance of glycolysis as the central mechanism producing ATP; nevertheless, as showed in Fig. 2, its level drops soon in the first day after slaughter, concurrently with the establishment of rigor mortis. Another feature delineated by gel analysis is the time course trend of adenylate kinase, which is upregulated at 44 days. This is a key enzyme in muscle energetic homeostasis, and it is known to be spatially organized in linear arrays along with creatine kinase [47], suggesting an interaction and a sort of mutual 'communication' about the muscular energetic state, particularly regarding adenine nucleotide flux [48]. The safeguard of cellular energy economy needs the promotion of high-energy phosphoryl transfer through the adenylate kinase system when there is a reduction of creatine kinase activity, especially under hypoxic stress [49]. From our results, it seems that adenylate kinase undergoes an upregulation at 44 days, with the simultaneous drop in the levels of creatine kinase; this evidence could be seen as an attempt to obtain ulterior ATP when ATP tokens are exhausted and the ADP/ATP ratio is high. Indeed, adenylate kinase is able to convert two ADP molecules into one AMP and one ATP; the hypothesis is confirmed by the AMP trend, showing a sudden rise at 44 days (Fig. 3).

As to photograph the oxidative state of the meat during the time course, we have monitored the levels of glutathione and glutathione disulfide (Fig. 3). The GSH/GSSG ratio is progressively decreasing, clearly indicating the overcoming of the oxidative stress on cellular defensive responses; in our previous work [5], we demonstrated the importance of the upregulation of pentose phosphate pathway as to cope with the oxidative stress (by means of the increase in NADPH production, able to restore GSH from GSSG), which is not further sustainable after day 17 (our previous data [5] show an evident drop in pentose phosphate pathway intermediates, consistently with the quick rise of GSSG/GSH ratio, Fig. 3). 
Regarding the analysis of the phosphoproteome, Western results are shown in Fig. 4, and the corresponding identifications are listed in Table 2 and Table 3 shows the phosphorylated peptides and respective phosphorylation sites of each protein as to confirm Western results. A global overview shows a strong degree of phosphorylations between 0 and 1 day after slaughter, indicating a sort of cellular response to the anoxic shock; from day 10 onward, phosphorylations seem to drastically decrease, and it is a logic result in the context of the exhaustion of ATP energetic tokens used as source of phosphate groups. Band C (Fig. 4) contains phosphorylated phosphoglucomutase (PGM) enzyme. It is one of the three enzymes (glycogen phosphorylase; debranching enzyme; PGM) whose sequential action leads to the release of a glucose-6-phosphate monomer from glycogen. Literature reports the enhancing effect of phosphorylation on PGM activity [50], and the Western results follow the expectations: muscle cells subjected to the anoxic conditions become needy of the lacking ATP no more produced by Krebs cycle and oxidative phosphorylation, so they veer to an anaerobic ATP production by increasing the degree of glycolysis, exploiting glycogen reservoirs and extracting glucose-6-phosphate monomers for directing them to glycolytic consumption.



Fig. 4. Phosphoproteomic outcome for the Western experiment.

Myo = myosin;

Pfk = phosphofructokinase;

AmpD1 = adenosine monophosphate deaminase 1

Synpo2= synaptopodin 2

Pgm $=$ phosphoglucomutase

Pgam $=$ phosphoglycerate mutase

$\mathrm{Tpi}=$ triosephosphate isomerase

CryAB $=\alpha B$-crystallin

Hsp B6= heat shock protein B6. 
Table 2. Identification of proteins evidenced as phosphorylated by the Western analysis.

\begin{tabular}{|c|c|c|c|c|c|c|c|}
\hline $\begin{array}{l}\text { Gel } \\
\text { band }\end{array}$ & $\mid \begin{array}{l}\text { MW } \\
(\mathbf{k D a})\end{array}$ & $\|$ Matches $^{\mathrm{a}} \|$ & \begin{tabular}{|l|} 
No. of \\
peptides \\
identified a $^{\text {a }}$
\end{tabular} & $\begin{array}{l}\text { Mascot } \\
\text { score }\end{array}$ & \begin{tabular}{|l} 
Sequence \\
coverage
\end{tabular} & $\begin{array}{l}\text { NCBI } \\
\text { accession no. }\end{array}$ & $\begin{array}{l}\text { Protein } \\
\text { taurus })\end{array}$ \\
\hline \multirow{2}{*}{ A } & 224,106 & $192(84)$ & $84(44)$ & 5406 & $47 \%$ & gi|261245063 & Myosin-2 \\
\hline & 223,764 & $187(81)$ & $81(44)$ & 5254 & $46 \%$ & gi|41386691 & Myosin-1 \\
\hline \multirow{3}{*}{ B } & 86,095 & $92(52)$ & |29 (20) & 1891 & $41 \%$ & $\mid$ gi|115497288 & $\begin{array}{l}\text { 6-Phosphofructokinase, } \\
\text { muscle type }\end{array}$ \\
\hline & 87,202 & $42(15)$ & $19(9)$ & 979 & $25 \%$ & gi|154152079 & AMP deaminase 1 \\
\hline & 135,765 & $31(8)$ & $11(4)$ & 481 & $12 \%$ & gi|139948281 & Synaptopodin-2 \\
\hline $\mathrm{C}$ & 61,836 & $100(37)$ & $30(12)$ & 1533 & $53 \%$ & gi|116004023 & Phosphoglucomutase-1 \\
\hline $\mathrm{D}$ & 28,838 & $8(3)$ & $4(2)$ & 164 & $8 \%$ & $\mid$ gi|84000195 & $\begin{array}{l}\text { Phosphoglycerate } \\
\text { mutase } 2\end{array}$ \\
\hline $\mathrm{E}$ & 28,838 & | $27(5)$ & | 7 (3) & 337 & $16 \%$ & $\mid$ gi|84000195 & $\begin{array}{l}\text { Phosphoglycerate } \\
\text { mutase } 2\end{array}$ \\
\hline $\mathrm{F}$ & 26,901 & $7(5)$ & $4(3)$ & 262 & $16 \%$ & |gi|61888856 & $\begin{array}{l}\text { Triosephosphate } \\
\text { isomerase }\end{array}$ \\
\hline G & 20,024 & | $45(5)$ & |12(2) & 466 & $49 \%$ & |gi|27805849 & $\begin{array}{l}\text { Alpha-crystallin } \\
\text { chain }\end{array}$ \\
\hline $\mathrm{H}$ & $\mid 17,525$ & | $42(1)$ & $4(1)$ & 237 & $17 \%$ & $\mid$ gi|119224088 & $\begin{array}{l}\text { Heat shock protein, } \\
\text { alpha-crystallin-related, } \\
\text { B6 }\end{array}$ \\
\hline
\end{tabular}

aValues between brackets indicate statistically significant peptides $(\mathrm{p}<0.05)$.

Table 3. Mass spectrometric confirmation of phosphorylated proteins identified in 1D-gel.

\begin{tabular}{|c|c|c|c|c|c|c|}
\hline \begin{tabular}{|l|} 
Spot \\
nam \\
e
\end{tabular} & Protein & $\begin{array}{l}\text { NCBInr } \\
\text { accession } \\
\text { no. }\end{array}$ & \begin{tabular}{|ll|}
\multicolumn{2}{|l|}{ Precurs } \\
or & ion \\
$\mathrm{m} / \mathrm{z}$ & \\
\end{tabular} & Charg & Peptide sequence & \begin{tabular}{|l} 
Masc \\
ot \\
Score
\end{tabular} \\
\hline \multirow[b]{2}{*}{ A } & Myosin-2 & $\begin{array}{l}\text { gi| } 2612450 \\
63\end{array}$ & 848.99 & $4+$ & $\begin{array}{l}\text { AAAEGGSSpSVFSMFDQTQIQ } \\
\text { EFK }\end{array}$ & $\begin{array}{l}78 \\
(\mathrm{ETD})\end{array}$ \\
\hline & Myosin-1 & $\mid \begin{array}{l}\text { gi|} \mid 4138669 \\
1\end{array}$ & 895.41 & $2+$ & |VQLLHTQNTSpLINTK & $\begin{array}{l}55 \\
\left(\mathrm{NL}^{\mathrm{a}}\right. \\
\left.\mathrm{MS}^{2}\right)\end{array}$ \\
\hline B & Synaptopodin-2 & \begin{tabular}{|l} 
gi||1399482 \\
81
\end{tabular} & 714.80 & $2+$ & AHSpPTPSLPAGWK & $\begin{array}{l}48 \\
(\mathrm{ETD}) \\
\end{array}$ \\
\hline \multirow{3}{*}{ C } & \multirow{3}{*}{$\begin{array}{l}\text { Phosphoglucomuta } \\
\text { se-1 }\end{array}$} & \multirow{3}{*}{$\mid \begin{array}{l}\text { gi| } 1160040 \\
23\end{array}$} & 585.76 & $2+$ & LSpGTGSAGAIR & $\begin{array}{l}96 \\
(\mathrm{ETD})\end{array}$ \\
\hline & & & 585.74 & $2+$ & LSGTpGSAGAIR & $\begin{array}{l}95 \\
(\mathrm{ETD}) \\
\end{array}$ \\
\hline & & & 762.66 & $3+$ & $\begin{array}{l}\text { AIGGIILTASpHNPGGPNGDFG } \\
\text { IK }\end{array}$ & $\begin{array}{l}66 \\
(\mathrm{ETD}) \\
\end{array}$ \\
\hline D & $\begin{array}{l}\text { Phophoglycerate } \\
\text { mutase } 2 \\
\end{array}$ & \begin{tabular}{|l} 
gi| 8400019 \\
5
\end{tabular} & 863.33 & $2+$ & |ERHYGGTpGLNKAET & $\begin{array}{l}50 \\
(\mathrm{ETD}) \\
\end{array}$ \\
\hline E & $\begin{array}{l}\text { Phophoglycerate } \\
\text { mutase } 2\end{array}$ & gi| 5400019 & 863.33 & $2+$ & ||ERHYGGTpGLNKAET & $\begin{array}{l}56 \\
(\mathrm{ETD})\end{array}$ \\
\hline
\end{tabular}




\begin{tabular}{|c|c|c|c|c|c|c|}
\hline \begin{tabular}{|l|} 
Spot \\
nam \\
e
\end{tabular} & Protein & $\begin{array}{l}\text { NCBInr } \\
\text { accession } \\
\text { no. }\end{array}$ & \begin{tabular}{|lr|}
\multicolumn{2}{|l|}{ Precurs } \\
or & ion \\
$\mathbf{m} / \mathbf{z}$ & \\
\end{tabular} & Charg & Peptide sequence & $\begin{array}{l}\text { Masc } \\
\text { ot } \\
\text { score }\end{array}$ \\
\hline \multirow{2}{*}{ F } & \multirow{2}{*}{$\begin{array}{l}\text { Triosephophate } \\
\text { iomerase }\end{array}$} & \multirow{2}{*}{\begin{tabular}{|l} 
gi $\mid 6188885$ \\
6
\end{tabular}} & 642.76 & $2+$ & |SNVSDAVAQSpAR & $\begin{array}{l}76 \\
(\mathrm{ETD})\end{array}$ \\
\hline & & & 703.80 & $2+$ & IIYGGSVTGATCK & $\begin{array}{l}59 \\
(\mathrm{ETD})\end{array}$ \\
\hline G & $\begin{array}{l}\text { Alpha-crystallin B } \\
\text { chain }\end{array}$ & $\mid \begin{array}{l}\text { gi } \mid 2780584 \\
9\end{array}$ & 771.81 & $2+$ & APSpWIDTGLSEMR & $\begin{array}{l}99 \\
(\mathrm{NL} \\
\left.\mathrm{MS}^{3}\right)\end{array}$ \\
\hline $\mathrm{H}$ & $\begin{array}{l}\text { Heat shock protein, } \\
\text { alpha-crystallin- } \\
\text { related, B6 }\end{array}$ & $\mid \begin{array}{l}\text { gil|1192240 } \\
88\end{array}$ & 715.36 & $2+$ & RASpAPLPGLSAPGR & $\left(\begin{array}{l}44 \\
(\mathrm{ETD})\end{array}\right.$ \\
\hline
\end{tabular}

a NL, neutral loss.

Phosphorylation of phosphofructokinase muscle-type (PFK-M) (Table 2, Fig. 4) is interpretable towards the same direction; this enzyme undergoes a strong phosphorylation between 0 and 1 day, as to indirectly potentiate its task to add a phosphate group to fructose-6-phosphate to obtain fructose-1,6-biphosphate, now fixed to glycolysis. PFK-M phosphorylation interferes with its regulation by allosteric modulators, such as lactate, able to inhibit its activity [51]. Therefore, its phosphorylation can be seen as a preventive action against the possible inhibition coming from the increasing lactate concentration; obviously muscle cells lose this preventing ability when ATP concentration is strongly reduced, clearly from day 10 onward. AMP-deaminase undergoes a phosphorylative regulatory modification which boosts its enzymatic activity [52] at days 0 and 1 (Fig. 4). It falls into the context of skeletal muscle energetic maintenance: the ATP consumption increases ADP levels, paving the way to the action of adenylate kinase; the consequently increasing AMP, which would impair muscular energetic flux, is maintained to a low level thanks to the boosted action of AMP deaminase, which converts AMP into IMP and NH3 (as the metabolomic IMP screen confirms, Fig. 3). From day 10, concomitantly to the dephosphorylation of AMP deaminase, IMP level begins to fall, to reach the minimum at day 44 (when AMP, indeed, rises exponentially); these time course trends demonstrate the progressive energetic impairment suffered by the skeletal muscle, which inevitably fails to maintain its homeostasis in the long term. All these data depict a picture of the battle fought by the muscle cells against the growing oxidative stress throughout the aging period. Obviously, cells have no possibilities to emerge victorious, and sooner or later they have to surrender and to pave the way to one of the programmed cell deaths; by means of 2D electrophoresis and mass spectrometry technologies, we have looked for peculiarities of the aging meat able to shed light on the duality autophagy/apoptosis. We investigated it on three different fields: the proteome, the metabolome and the phosphoproteome. We discuss our results in the next section.

\subsection{Omic clues towards apoptosis}

Our 'omic' time course analysis shows interesting hints about the duality autophagy/apoptosis, indirectly suggesting a propensity of the slaughtered muscle cells for the apoptotic solution; Fig. 5 summarizes the results and their connections with apoptosis, and we will refer to it along the following discussion. First of all, we want to consider the trend of two proteins belonging to the family of heat shock proteins (HSPs), HSPB6 and $\alpha$ B-crystallin. The importance of HSP into the muscle-to-meat conversion has been recently recognized and associated to meat tenderization [2] and [53], although there is no clear hypothesis about the biological mechanisms underpinning 
postmortem events. Furthermore, a link between HSP and apoptosis [54], [55] and [56] is ascertained, evidence that endorses the attention on HSP identifications in our time course experiment. HSPB6 has clear roles in smooth and cardiac muscles, while in the skeletal muscle it is less understood [57]. Gusev and colleagues [58] described for HSPB6 a protective role against apoptosis in cardiomyocytes, by means of the inhibition of the activation of procaspase 3 to caspase 3. This outcome is the final step of a signaling cascade walking through the phosphorylation of HSPB6 by protein kinase A (PKA), which in turn has to be activated by high levels of cAMP; our metabolomic time course investigation of cAMP trend shows a sudden decrease soon from day 1 (Fig. 3); if we hypothesize a similar mechanism of action for HSPB6 in the skeletal muscle, the sudden cAMP decrease could trigger PKA inactivation to avoid HSPB6 phosphorylation (spot 371, probably containing the phosphorylated form of HSPB6, decreases along the time course), which at this point is no more able to inhibit caspase 3 activation; phosphoproteomic analysis confirms the presence of the phosphorylated form of HSPB6, as indicated in Fig. 4 and Table 2. The downward trend of unphosphorylated HSPB6 (the more basic spot, 370; Table 1, Fig. 1) may be read in the same direction, as to foster the apoptotic solution to muscle cells: HSPB6 is able to interact with Bax, a proapoptotic protein, hampering its translocation to the mitochondria where it performs its proapoptotic function [59]; the decrease in HSPB6 levels discourages this prosurvival interaction (Fig. 5).

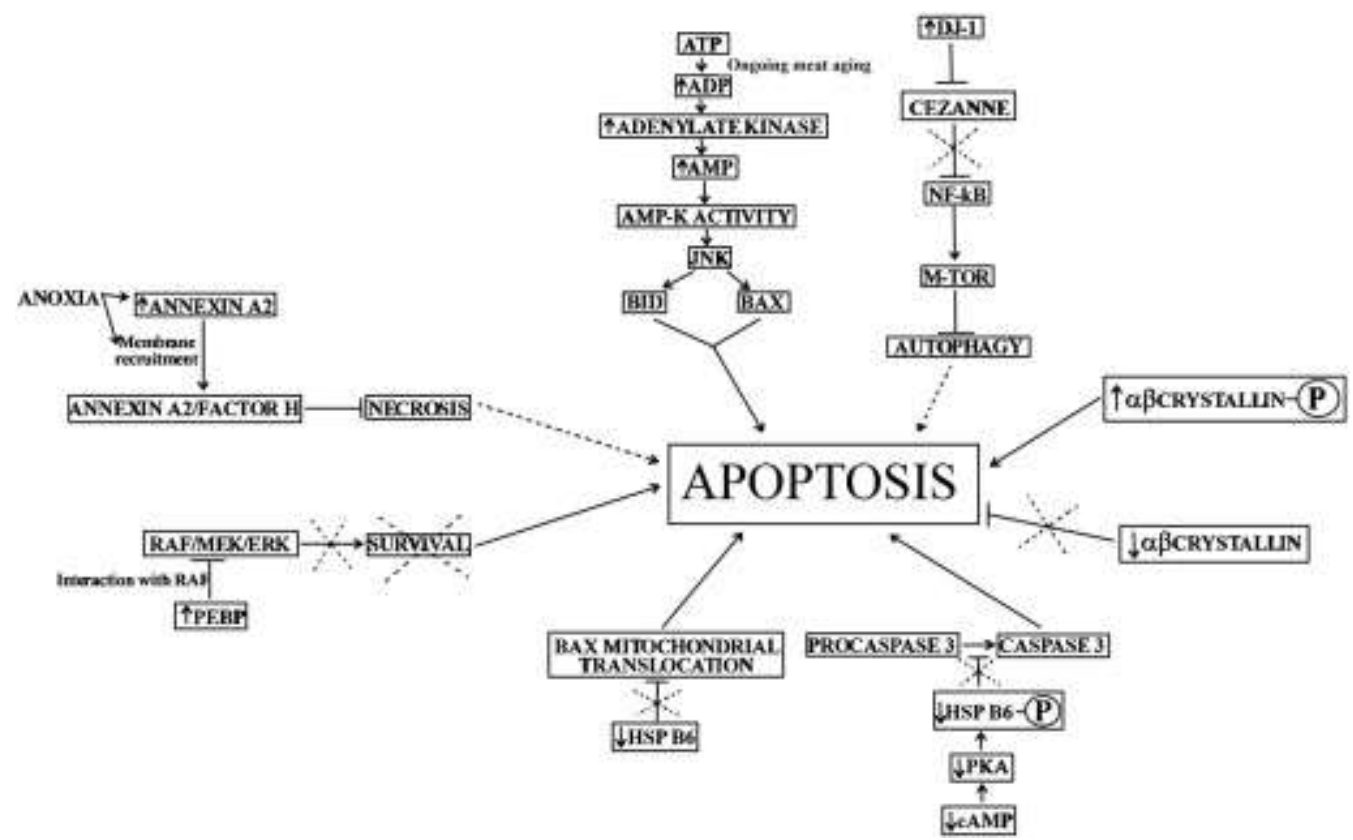

Fig. 5. Summary of pathways linking some 'omic' results to apoptosis.

$\alpha \mathrm{B}$-crystallin protein has been identified in four different spots in our 2D time course analysis; spots 367 and 530 show a downward trend from day 17, while 363 and 456 show an upward trend. We have different pIs, and this phenomenon is attributed to posttranslational phosphorylation, able to acidify the pI of $\alpha \mathrm{B}$-crystallin [60]; we confirmed the presence of the phosphorylated form of $\alpha \mathrm{B}$ crystallin by its detection and identification in Western analysis. Many studies have been conducted on the possible role of this protein in apoptosis: Ray and colleagues [61] demonstrated that transgene overexpression of $\alpha \mathrm{B}$-crystallin confers simultaneous protection against cardiomyocyte apoptosis and necrosis during myocardial ischemia and reperfusion; Kamradt and colleagues [62] found that wild-type $\alpha \mathrm{B}$-crystallin promotes xenograft tumor growth and inhibits TRAIL-induced apoptosis in vivo in a murine model, while a pseudophosphorylated $\alpha \mathrm{B}$-crystallin mutant, impaired in its antiapoptotic function, inhibits xenograft tumor growth; Dou and colleagues [63] observed that overexpression of $\alpha \mathrm{B}$-crystallin protects a model of retinal pigment epithelial cell from ERstress induced apoptosis, while the apoptotic answer is increased when these cells are $\alpha \mathrm{B}$-crystallin- 
deficient. All these evidences lead us to hypothesize an apoptotic boost by the $\alpha \mathrm{B}$-crystallin in our time course, because of the upward trend of the phosphorylated form, soon from day 1 (spots 363, 456), which seems to promote apoptosis, and of the downward trend of the unphosphorylated form (spots 367, 530), which in turn seems able to inhibit apoptosis (Fig. 5). Notably, the full proapoptotic potential in terms of $\alpha \mathrm{B}$-crystallin seems to be completely expressed from day 17 . Recalling the aforementioned increase in adenylate kinase at day 44 , confirmed by the sudden rise in [AMP], we can hypothesize a link between the adenylate kinase metabolic monitoring system and the apoptotic cascade, as evidenced in Fig. 5: the ATP consumption fuels [ADP] growing, which in turn, as evident at day 44, turns on the activity of adenylate kinase for the extreme but futile attempt to restore ATP reservoirs and [AMP] rises, promoting the activities of the 'AMP sensor' enzymes [48]. Among these members, AMP-dependent kinase (AMPK) is able to induce the JNK pathway (Fig. 5), a known apoptotic inducer in a model of MIN6 beta-cell line [64]. Particular attention must be paid to spot 472, annexin A2, which shows an upward trend in the central part of aging period (days 10 and 17; Table 1) and a final decrement slightly below the postslaughter level. This protein is more or less directly linked to apoptosis, as it has been shown its exposure on surfaces of apoptotic cells [65], and it falls into the context of $\left[\mathrm{Ca}^{2+}\right]$ increase in postmortem muscle cytoplasm while the sarcoplasmic reticulum gradually loses this ion [66]; the increase in $\left[\mathrm{Ca}^{2+}\right]$ could be linked to the upregulation of annexin $\mathrm{A} 2$, which undergoes plasma membrane recruitment in condition of anoxic stress [67]. It is interesting to point out the discovery recently made by Leffler and colleagues [65] about the ability of annexin A2 present on apoptotic cells to bind factor $\mathrm{H}$; it is well known that during ischemia (a situation comparable with the anoxic muscles of the slaughtered animals) there are hypoxia, lactic acidosis, cell swelling and depletion in ATP tissutal reservoirs; the increased concentration of ROS contributes to eventual tissue necrosis [68] led by an inappropriate activation of the complement mechanism [69]. Factor $\mathrm{H}$ is a $155 \mathrm{kDa}$ glycoprotein able to regulate complement protein activity in order to prevent the formation of anaphylatoxins and membrane attack complexes, with the risk of subsequent necrosis; the finding made by Leffler et al. about the factor H-binding ability of annexin A2 implies the deduction of a possible proapoptotic evidence in the upregulation of annexin A2 during the time course, whose binding potential could be exploited to avert the necrotic risk thanks to the recruited factor $\mathrm{H}$ functions. So, following the conclusions of Leffler about the exposition of annexin A2 by apoptotic cells, we can speculate a concomitant upregulation of this protein towards the apoptotic road in muscle/meat cells (Fig. 5). Another noteworthy identification is the spot 344, containing the protein DJ-1 (progressive upregulation from day 10 onward; Table 1). There are a number of evidences stating that DJ-1 is directly linked to anoxia conditions and that its oxidative stress-related function seems to be specific: a work conducted by Meulener and colleagues [70] on DJ-1 deficient flies treated with ROS-generating compound shows that these animals were susceptible to oxidative damages, but not to alternative forms of stress. Another recent study [71] demonstrates the ability of DJ-1 to positively regulate NF-kB, thanks to the upstream DJ-1 binding to the deubiquitinating enzyme Cezanne that loses the inhibitory effect exerted on NF-kB. When active, under conditions of high ROS concentrations, NF-kB functions as an autophagic repressor by means of mTOR, so we can hypothesize that the stated upregulation of protein DJ-1 in aging meat could fuel NF-kB antiautophagic activity; in the light of DJ-1 indirect antiautophagic effect and of our proteomic results, this speculation contributes to the prevailing of the apoptotic hypothesis on the autophagic one during meat aging (Fig. 5). Spot 365 has been identified as phosphatidylethanolamine-binding protein 1 (PEBP, also known as RKIP, Raf-1 kinase inhibitor protein; Table 1); we pointed our attention on this differential 2D-GE result because RKIP is linked with the Raf pathway. Raf is the upstream pawn of this evolutionarily conserved pathway comprising the sequential activities of three protein kinases: RAF, MEK, and ERK. This signaling pathway is able to transmit extracellular signals into nuclear instructions, particularly those with cellular survival meaning against apoptosis [72]; RKIP is a member of the phosphatidylethanolamine binding proteins shown to disrupt RAF/MEK/ERK signaling pathway [73], thanks to its physical interaction with RAF. RKIP has 
thereby a proapoptotic function, and the upregulation demonstrated in our proteomic study is another brick put for the apoptotic hypothesis (Fig. 5). We have discussed the increasing rate of the proteolytic events appearing into the aging meat, by the metabolomic point of view in our previous work (through the progressive increase in single amino acid concentrations) [5], and by the proteomic point of view, especially in the previous section; another interesting evidence mentioned in the Proteolysis section is referred to spot 472, identified as a $31 \mathrm{kDa}$ fragment of actin (Fig. 1, Table 1), a known structural/functional pivotal protein in the muscles, and we decided to resume it in this section because of the implications regarding apoptosis: indeed, this specific $31 \mathrm{kDa}$ fragment is considered as an apoptotic marker [74] and [75]. It is clearly appreciable from Fig. 6 the progressive upward trend of this fragment, attesting the presence of apoptosis and its increase among meat cells throughout the aging period.

M

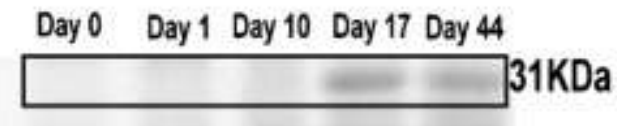

Day 0 Day 1 Day 10 Day 17 Day 44

西

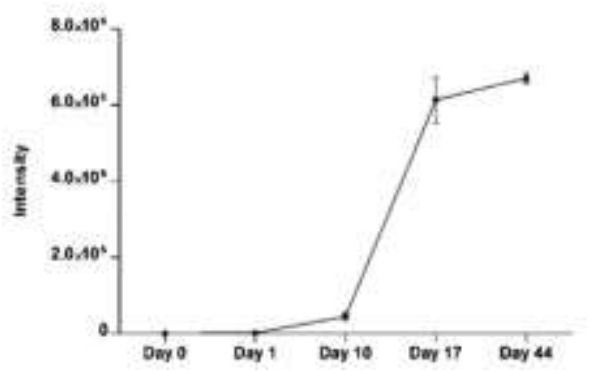

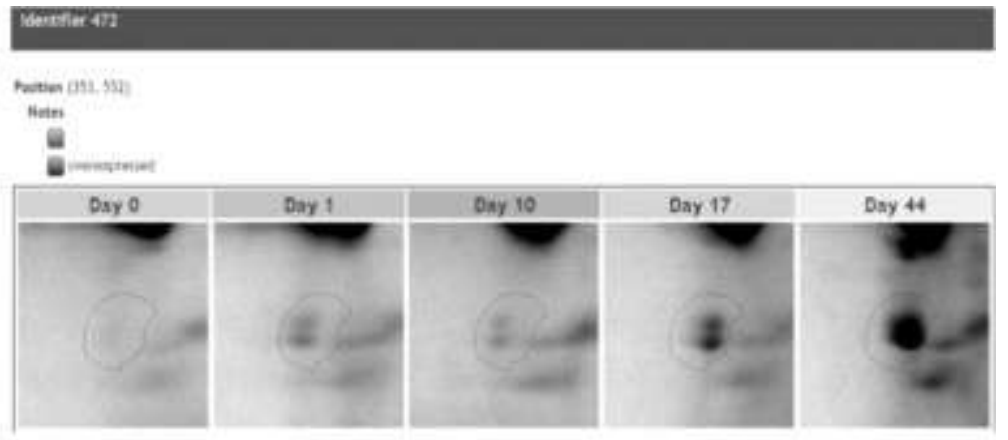

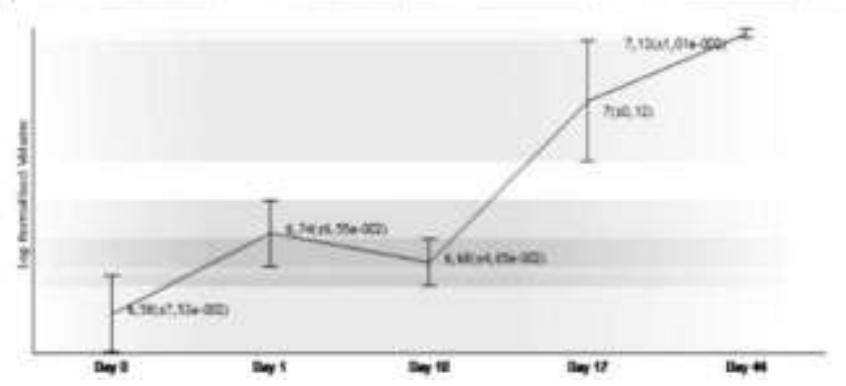

Fig. 6. Upward trend of the $31 \mathrm{kDa}$ actin fragment; on the left, the $31 \mathrm{kDa}$ band of a $1 \mathrm{D}$ gel showing an increase throughout the time course, confirmed and identified on the $2 \mathrm{D}$ gel on the right; we also show spot 472 from the 2D gel along the time course; the intensity values for the two gels are represented as mean $\pm \mathrm{SD}$.

The analysis of phosphorylated proteins revealed a time-specific phosphorylation of myosins 2 and 1 at day 1; this is, on average, the period during which rigor mortis begins to dissolve, and myosin phosphorylation could be seen as a factor influencing the activity of the proteolytic systems intervening for muscle architectural destructuration. Myosin 1 and 2 phosphorylation is not a novel or unexpected finding [76]; recently, Iwasaki and colleagues [77] have produced compelling evidences about the promotion of a hyperphosphorylated state of myosin 2 in apoptotic cells, due to the inhibition of the myosin 2-dephosphorylating activity of MYPT enzyme. Our result could suggest a sort of apoptotic programming of muscle cells even from the very beginning of rigor mortis dissolution.

Band B (Fig. 4) hides synaptopodin 2, indicating a phosphorylation starting from day 0 and reaching a high degree in day 1 . This protein is normally localized at Z-disks, but under stress conditions it is removed from the cytoplasm and transferred to the nucleus [78]; synaptopodin 2 nuclear import is possible only when it is phosphorylated [79]. The phosphorylation state showed by our results suggests the nuclear translocation of synaptopodin 2 caused by the increasing 
oxidative stress. Reminding the tumor-suppressor role of nuclear-imported synaptopodin 2 demonstrated by Sanchez-Carbayo and colleagues [80], we could infer the proapoptotic role played by this protein in the progression of meat maturation, adding another evidence favorable to apoptosis way.

From the metabolomic point of view, we have already mentioned the decreasing trend of the GSH/GSSG ratio throughout the 44 days (Fig. 3). This ratio is a key indicator for an ongoing apoptosis [81] and [82], even if the precise role of GSH/GSSG balance is not clearly understood, and further complicated by cell-type specificity and nature of proapoptotic stimuli. We have also investigated the time course trend of a particular amino acid, taurine, because of its known abilities to inhibit apoptosis [83]; it is thought to have putative antioxidant function against ROS, inhibitory effect on p53 and NF-kB proapoptotic pathway, and a prosurvival stimulating effect on PI3K/Akt pathway [84]; Fig. 7 shows a downward trend sustaining the apoptotic hypothesis. On the contrary, the trend of nitrotyrosine has a constant slight increase until day 17 and undergoes a strong rise at day 44; we have considered this particular metabolite because of its role as an apoptotic marker [85] and [86] and as an indicator of nitrosative stress (that is, the production of RNS, reactive nitrogen species, coming from the accumulation of superoxide radical reacting with nitric oxide [87]). Taurine and nitrotyrosine time course trends confirm the apoptotic way for meat evolution, and the increasing degree of the apoptotic events throughout aging.

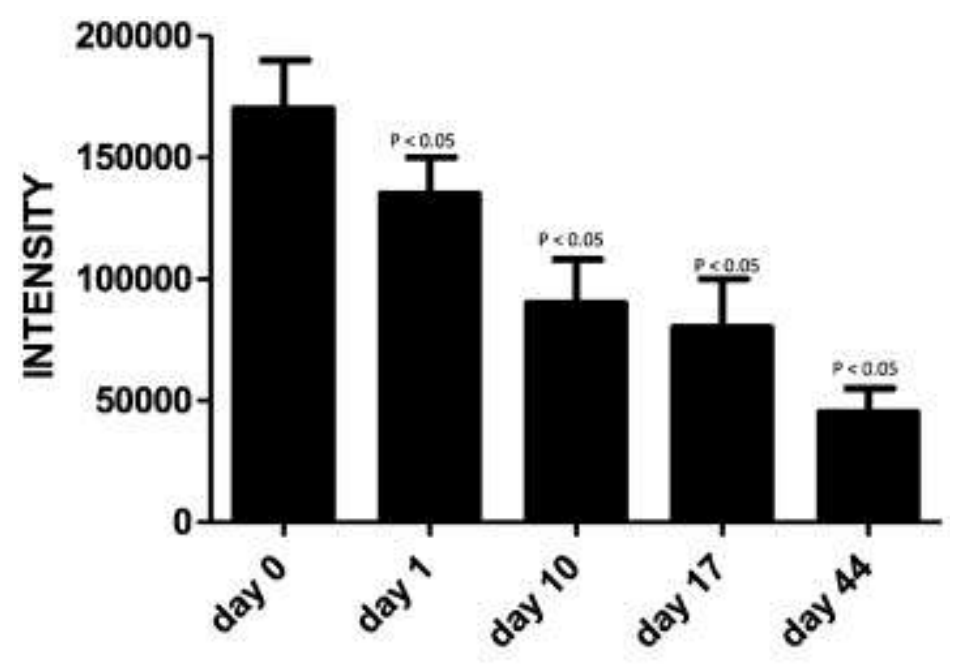

TAURINE

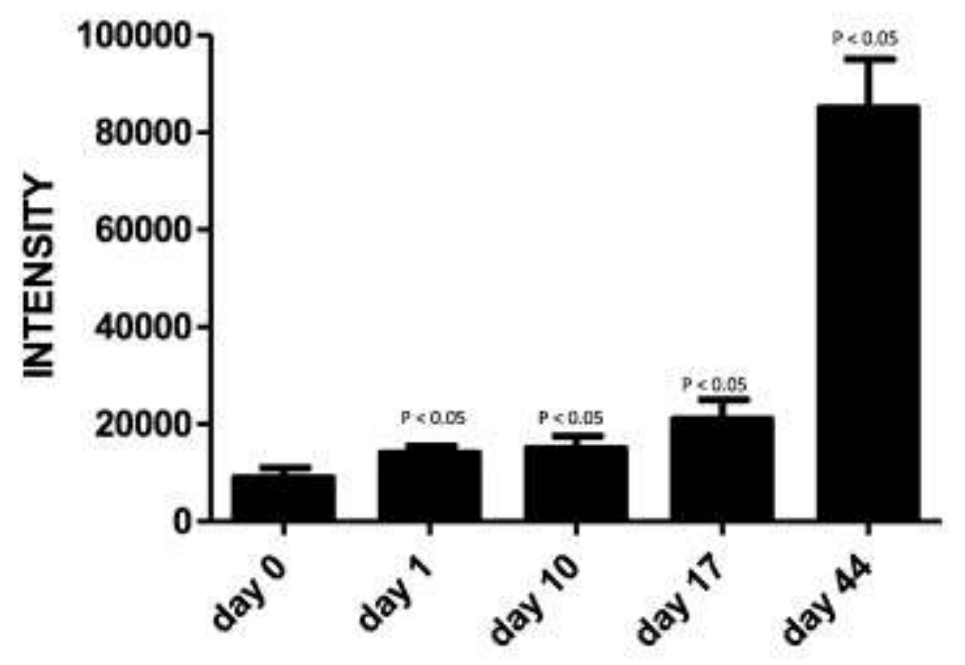

NITROTYROSINE 
Fig. 7. Taurine and nitrotyrosine time course trends represented as mean \pm SEM. The statistically significant variations evidenced with $\mathrm{p}<0.05$ refer to day 0 against each other.

\section{Conclusions}

This work is based on an 'omic' study led to obtain a deeper glance into the biomolecular evolutions suffered by Piedmontese longissimus thoracis muscle cells during the 44 day process of muscle-to-meat conversion. In particular, among our proteomic, phosphoproteomic and metabolomic results we looked for some clues able to shed light on the controversial debate arisen about the destiny of the skeletal muscle cells of slaughtered animals; they are fatally directed to death, and there are three main feasible ways: the exclusion of necrosis, which is not the way walked by maturing palatable meat, paves the way to the famous duality autophagy/apoptosis. Our omic evidences suggest apoptosis as the only choice: we have discussed the peculiarities of the ongoing oxidative stress integrating proteome, phosphoproteome and metabolome indications, and then we pointed the attention on the indirect clues able to bring out the predominance of the apoptotic hypothesis on the autophagic one; we didn't find any indication about a hypothetic cellular autophagic response. Our suggestion is that apoptosis is the opted behavior, at least in the specific kind of meat considered. We want to underline that this work does not claim to be the incontrovertible solution of the eternal contrast between meat autophagy and meat apoptosis sustainers, due to the extreme variability inherent in different kinds of species, muscles and animal management. When considering different samples, the biological mechanism could be different and could also involve autophagy or a crosstalk between autophagy and apoptosis. Further studies are needed to verify if a common, underlying mechanism for any kind of muscle-to-meat conversion does exist.

\section{Conflict of interest}

The author(s) confirm that this article content has no conflicts of interest.

\section{Acknowledgments}

This research has been supported by funds from the "Fondazione Cassa di Risparmio di Cuneo. Bando ricerca scientifica 2011 - progetto numero 1837.VL, AL, and LZ have been supported by the "GENZOOT" research programme, funded by the Italian Ministry of Agricultural, Food and Forestry Policies (Ministero delle Politiche Agricole, Alimentari e Forestali).

\section{Appendix A. Supplementary data}

The following is the Supplementary data to this article.

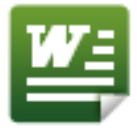

Supplementary Table S1.

Detailed MS/MS peptide sequence analysis of successfully identified proteins of 2D-SDSPAGE. 
Supplementary Table S2.

Detailed MS/MS peptide sequence analysis of successfully identified proteins evidenced as phosphorylated by Western blotting analysis.

\section{References}

[1] V. Sierra, M. Oliván Role of mitochondria on muscle cell death and meat tenderization Recent Pat Endocr Metab Immune Drug Discov, 7 (2) (2013), pp. 120-129

[2] A. Ouali, C.H. Herrera-Mendez, G. Coulis, S. Becila, A. Boudjellal, L. Aubry, et al. Revisiting the conversion of muscle into meat and the underlying mechanisms. Meat Sci, 74 (2006), pp. 44-58

[3] M.A. Sentandreu, G. Coulis, A. Ouali. Role of muscle endopeptidases and their inhibitors in meat tenderness. Trends Food Sci Technol, 13 (2002), pp. 400-421

[4] A. D'Alessandro, L. Zolla. Meat science: from proteomics to integrated omics towards system biology. J Proteomics, 78 (2013), pp. 558-577

[5] A. Lana, V. Longo, A. Dalmasso, A. D'Alessandro, M.T. Bottero, L. Zolla. Omics integrating physical techniques: aged Piedmontese meat analysis. Food Chem, 172 (2015), pp. 731-741

[6] M.P. Murphy. How mitochondria produce reactive oxygen species. Biochem J, 417 (1) (2009), pp. $1-13$

[7] I. Kim, S. Rodriguez-Enriquez, J.J. Lemasters. Selective degradation of mitochondria by mitophagy. Arch Biochem Biophys, 462 (2007), pp. 245-253

[8] A. Coto-Montes. Mitochondrion: an organelle more and more implication in new processes. Recent Pat Endocr Metab Immune Drug Discov, 7 (2) (2013), pp. 83-85

[9] F.L. Muller, Y. Liu, H. Van Remmen. Complex III releases superoxide to both sides of the inner mitochondrial membrane. J Biol Chem, 279 (2004), pp. 49064-49073

[10] M.L. Urso, P.M. Clarkson. Oxidative stress, exercise, and antioxidant supplementation. Toxicology, 189 (2003), pp. 41-54

[11] A. Fidzianska, A. Kaminska, Z. Glinka. Muscle cell death. Ultrastructural differences between muscle cell necrosis and apoptosis. Neuropatol Pol, 29 (1991), pp. 19-28

[12] J.F. Kerr, A.H. Wyllie, A.R. Currie. Apoptosis: a basic biological phenomenon with wideranging implications in tissue kinetics. Br J Cancer, 26 (1972), pp. 239-25

[13] S. Ponsuksili, Y. Du, F. Hadlich, P. Siengdee, E. Murani, M. Schwerin, K. Wimmers. Correlated mRNAs and miRNAs from co-expression and regulatory networks affect porcine muscle and finally meat properties. BMC Genomics, 14 (2013), p. 533 
[14] A.S. Becila, C. Herrera-Mendez Hernan, G. Coulis, R. Labas, T. Astruc, B. Picard, et al. Postmortem muscle cells die through apoptosis. Eur Food Res Technol, 231 (2010), pp. 485-493

[15] Z. Xie, D.J. Klionsky. Autophagosome formation: core machinery and adaptations. Nat Cell Biol, 9 (2007), pp. 1102-1109

[16] D. Gozuacik, A. Kimchi. Autophagy as a cell death and tumor suppressor mechanism. Oncogene, 23 (2004), pp. 2891-2906

[17] K. Hollung, A.M. Timperio, M. Olivan, C. Kemp, A. Coto-Montes, V. Sierra, et al. Systems biology: a new tool for farm animal science. Curr Protein Pept Sci, 15 (2014), pp. 100-117

[18] G. Mariño, M. Niso-Santano, E.H. Baehrecke, G. Kroemer. Self-consumption: the interplay of autophagy and apoptosis. Nat Rev Mol Cell Biol, 15 (2014), pp. 81-94

[19] S.W. Ryter, K. Mizumura, A.M.K. Choi. The impact of autophagy on cell death modalities. Int J Cell Biol, 2014 (2014) [Article ID 502676, 12 pp.],

[20] A. Coto-Montes, J.A. Boga, S. Rosales-Corral, L. Fuentes-Broto, D.X. Tan, R.J. Reiter

. Role of melatonin in the regulation of autophagy and mitophagy: a review. Mol Cell Endocrinol, 361 (2012), pp. 12-23

[21] R. Scherz-Shouval, Z. Elazar. ROS, mitochondria and the regulation of autophagy. Trends Cell Biol, 17 (2007), pp. 422-427

[22] Y. Chen, M.B. Azad, S.B. Gibson. Superoxide is the major reactive oxygen species regulating autophagy. Cell Death Differ, 16 (2009), pp. 1040-1052

[23] A. Hamacher-Brady, N.R. Brady, S.E. Logue, M.R. Sayen, M. Jinno, L.A. Kirshenbaum, et al. Response to myocardial ischemia/reperfusion injury involves Bnip3 and autophagy. Cell Death Differ, 14 (2007), pp. 146-157

[24] S.E. Wohlgemuth, A.Y. Seo, E. Marzetti, H.A. Lees, C. Leeuwenburgh. Skeletal muscle autophagy and apoptosis during aging: effects of calorie restriction and life-long exercise. Exp Gerontol, 45 (2010), pp. 138-148

[25] C. Mammucari, R. Rizzuto. Signaling pathways in mitochondrial dysfunction and aging. Mech Ageing Dev, 131 (2010), pp. 536-543

[26] E.M. Insani, A. Eyherabide, G. Grigioni, A.M. Sancho, N.A. Pensel, A.M. Descalzo. Oxidative stability and its relationship with natural antioxidants during refrigerated retail display of beef produced in Argentina. Meat Sci, 79 (2008), pp. 444-452

[27] N.G. Gregory. Animal welfare at markets and during transport and slaughter. Meat Sci, 80 (2008), pp. 2-11

[28] V. Van de Perre, L. Permentier, S. De Bie, G. Verbeke, R. Geers. Effect of unloading, lairage, pig handling, stunning and season on $\mathrm{pH}$ of pork. Meat Sci, 86 
[29] F. Talamo, C. D'Ambrosio, S. Arena, P. Del Vecchio, L. Ledda, G. Zehender, et al.. Proteins from bovine tissues and biological fluids: defining a reference electrophoresis map for liver, kidney, muscle, plasma and red blood cells. Proteomics, 3 (2003), pp. 440-460

[30] A. Shevchenko, M. Wilm, O. Vorm, M. Mann. Mass spectrometric sequencing of proteins from silver-stained polyacrylamide gels. Anal Chem, 68 (1996), pp. 850-858

[31] T.E. Thingholm, T.J. Jorgensen, O.N. Jensen, M.R. Larsen. Highly selective enrichment of phosphorylated peptides using titanium dioxide. Nat Protoc, 1 (2006), p. 1929

[32] A. D'Alessandro, S. Rinalducci, C. Marrocco, V. Zolla, F. Napolitano, L. Zolla. Love me tender: an omic window on the bovine meat tenderness network. J Proteomics, 75 (2012), p. 4360

[33] A. D'Alessandro, S. Rinalducci, C. Marrocco, V. Zolla, F. Napolitano, L. Zolla. Love me tender: an omics window on the bovine meat tenderness network. J Proteomics, 75 (14) (2012), pp. $4360-4380$

[34] M.F. Clasquin, E. Melamud, J.D. Rabinowitz. LC-MS data processing with MAVEN: a metabolomic analysis and visualization engine. Curr Protoc Bioinformatics, 14 (2012) [Unit 14.11]

[35] M. Kanehisa, S. Goto. KEGG: Kyoto Encyclopedia of Genes and Genomes. Nucleic Acids Res, 28 (1) (2000), pp. 27-30

[36] M. Koohmaraie. Muscle proteinases and meat aging. Meat Sci, 36 (1994), pp. 93-104

[37] F.B. Luciano, A.A. Anton, C.F. Rosa. Biochemical aspects of meat tenderness: a brief review. Arch Zootec, 56 (2007), pp. 1-8

[38] G. Paredi, S. Raboni, E. Bendixen, A.M. de Almeida, A. Mozzarelli. "Muscle to meat" molecular events and technological transformations: the proteomics insight. J Proteomics, 75 (14) (2012), pp. 4275-4289

[39] L. Murgiano, A. D'Alessandro, M.G. Egidi, A. Crisà, G. Prosperini, A.M. Timperio, et al. Proteomics and transcriptomics investigation on longissimus muscles in large white and Casertana pig breeds. J Proteome Res, 9 (12) (2010), pp. 6450-6466

[40] A. D'Alessandro, C. Marrocco, V. Zolla, M. D'Andrea, L. Zolla. Meat quality of the longissimus lumborum muscle of Casertana and large white pigs: metabolomics and proteomics intertwined. J Proteomics, 75 (2) (2011), pp. 610-627

[41] A. Asghar, N.T. Yeates. The mechanism for the promotion of tenderness in meat during the post mortem process: a review. Crit Rev Food Sci Nutr, 10 (2) (1978), pp. 115-145

[42] E. Huff-Lonergan, W. Zhang, S.M. Lonergan. Biochemistry of postmortem muscle: lessons on mechanisms of meat tenderization. Meat Sci, 86 (1) (2010), pp. 184-195

[43] C. Kemp, T. Parr. Advances in apoptotic mediated proteolysis in meat tenderization. Meat Sci, 92 (2012), pp. 252-259 
[44] S. Muroya, M. Ohnishi-Kameyama, M. Oe, I. Nakajima, K. Chikuni. Postmortem changes in bovine troponin $\mathrm{t}$ isoforms on two-dimensional electrophoretic gel analyzed using mass spectrometry and western blotting: the limited fragmentation into basic polypeptides. Meat Sci, 75 (2007), pp. 506-514

[45] S. Rinalducci, N. Campostrini, P. Antonioli, P.G. Righetti, P. Roepstorff, L. Zolla. Formation of truncated proteins and high-molecular-mass aggregates upon soft illumination of photosynthetic proteins. J Proteome Res, 4 (2005), pp. 2327-2337

[46] S.P. Bessman. The creatine phosphate energy shuttle: the molecular asymmetry of a "pool". Anal Biochem, 161 (2) (1987), pp. 519-523

[47] G. Wegmann, E. Zanolla, H.M. Eppenberger, T. Wallimann. In situ compartmentation of creatine kinase in intact sarcomeric muscle: the acto-myosin

[48] P.P. Dzeja, A. Terzic. Phosphotransfer networks and cellular energetic. J Exp Biol, 206 (2003), pp. 2039-2047

[49] E. Janssen, P.P. Dzeja, F. Oerlemans, A.W. Simonetti, A. Heerschap, A. de Haan, et al. Adenylate kinase 1 gene deletion disrupts muscle energetic economy despite metabolic rearrangement. EMBO J, 19 (2000), pp. 6371-6381

[50] A. Gururaj, C.J. Barnes, R.K. Vadlamudi, R. Kumar. Regulation of phosphoglucomutase 1 phosphorylation and activity by a signaling kinase. Oncogene, 23 (2004), pp. 8118-8127

[51] T.C. Leite, D. Da Silva, R.G. Coelho, P. Zancan, M. Sola-Penna. Lactate favours the dissociation of skeletal muscle 6-phosphofructo-1-kinase tetramers down-regulating the enzyme and muscle glycolysis. Biochem J, 408 (2007), pp. 123-130

[52] E.K. Tovmasian, R.L. Hairapetian, E.V. Bykova, S.E. Severin Jr., A.V. Haroutunian. Phosphorylation of the skeletal muscle AMP-deaminase by protein kinase C. FEBS Lett, 259 (2) (1990), pp. 321-323

[53] N. Guillemin, M. Bonnet, C. Jurie, B. Picard. Functional analysis of beef tenderness. J Proteomics, 75 (2) (2011), pp. 352-365

[54] H.M. Beere. "The stress of dying": the role of heat shock proteins in the regulation of apoptosis. J Cell Sci, 117 (2004), pp. 2641-2651

[55] S. Takayama, J.C. Reed, S. Homma. Heat-shock proteins as regulators of apoptosis. Oncogene, 22 (56) (2003), pp. 9041-9047

[56] D. Lanneau, M. Brunet, E. Frisan, E. Solary, M. Fontenay, C. Garrido

Heat shock proteins: essential proteins for apoptosis regulation. J Cell Mol Med, 12 (3) (2008), pp. 743-761 
[57] C.M. Dreiza, P. Komalavilas, E.J. Furnish, C.R. Flynn, M.R. Sheller, C.C. Smoke, et al. The small heat shock protein, HSPB6, in muscle function and disease. Cell Stress Chaperones, 15 (2010), pp. 1-11

[58] N.B. Gusev, O.V. Bukach, S.B. Marston Structure, properties, and probable physiological role of small heat shock protein with molecular mass $20 \mathrm{kD}$ (Hsp20, HspB6). Biochemistry, 70 (6) (2005), pp. 629-637

[59] G.C. Fan, E.G. Kranias. Small heat shock protein 20 (HspB6) in cardiac hypertrophy and failure. J Mol Cell Cardiol, 51 (2011), pp. 574-577

[60] N. Golenhofen, W. Ness, R. Koob, P. Htun, W. Schaper, D. Drenckhahn. Ischemia-induced phosphorylation and translocation of stress protein alpha B-crystallin to $\mathrm{Z}$ lines of myocardium. Am J Physiol, 274 (1998), pp. 1457-1464

[61] P.S. Ray, J.L. Martin, E. Swanson, H. Otani, W.H. Dillmann, D.K. Das. Transgene overexpression of $\alpha \mathrm{B}$-crystallin confers simultaneous protection against cardiomyocyte apoptosis and necrosis during myocardial ischemia and reperfusion. FASEB J, 15 (2001), pp. 393-402

[62] M.C. Kamradt, M. Lu, M.E. Werner, T. Kwan, F. Chen, A. Strohecker, et al.. The small heat shock protein alpha B-crystallin is a novel inhibitor of TRAIL-induced apoptosis that suppresses the activation of caspase-3. J Biol Chem, 280 (12) (2005), pp. 11059-11066

[63] G. Dou, P.G. Sreekumar, C. Spee, S. He, S.J. Ryan, R. Kannan, et al. Deficiency of $\alpha$ B crystallin augments er stress-induced apoptosis by enhancing mitochondrial dysfunction. Free Radic Biol Med, 53 (5) (2012), pp. 1111-1122

[64] B.A. Kefas, Y. Cai, Z. Ling, H. Heimberg, L. Hue, D. Pipeleers, et al.. AMP-activated protein kinase can induce apoptosis of insulin-producing MIN6 cells through stimulation of c-Jun-Nterminal kinase. J Mol Endocrinol, 30 (2) (2003), pp. 151-161

[65] J. Leffler, A.P. Herbert, E. Norström, C.Q. Schmidt, P.N. Barlow, A.M. Blom, et al.. AnnexinII, DNA, and histones serve as factor $\mathrm{H}$ ligands on the surface of apoptotic cells. J Biol Chem, 285 (6) (2010), pp. 3766-3776

[66] X. Vignon, J. Beaulaton, A. Ouali. Ultrastructural localization of calcium in post-mortem bovine muscle: a cytochemical and X-ray microanalytical study. Histochem J, 21 (1989), pp. 403411

[67] K. Monastyrskaya, F. Tschumi, E.B. Babiychuk, D. Stroka, A. Draeger. Annexins sense changes in intracellular pH during hypoxia. Biochem J, 409 (2008), pp. 65-75

[68] B.B. Rubin, A. Romaschin, P.M. Walker, D.C. Gute, R.J. Korthuis. Mechanisms of postischemic injury in skeletal muscle: intervention strategies. J Appl Physiol, 80 (1996), pp. 369387

[69] P.A. Ward. Role of complement in lung inflammatory injury. Am J Pathol, 149 (1996), pp. $1081-1086$ 
[70] M. Meulener, A.J. Whitworth, C.E. Armstrong-Gold, P. Rizzu, P. Heutink, P.D. Wes, et al. Drosophila DJ-1 mutants are selectively sensitive to environmental toxins associated with Parkinson's disease. Curr Biol, 15 (2005), pp. 1572-1577

[71] R.S. McNally, B.K. Davis, C.M. Clements, M.A. Accavitti-Loper, T.W. Mak, J.P. Ting. DJ-1 enhances cell survival through the binding of Cezanne, a negative regulator of NF-KappaB. J Biol Chem, 286 (6) (2011), pp. 4098-4106

[72] M.S. Murakami, D.K. Morrison. Raf-1 without MEK?. Sci STKE, 99 (2001), p. pe30

[73] G. Odabaei, D. Chatterjee, A.R. Jazirehi, L. Goodglick, K. Yeung, B. Bonavida. Raf-1 kinase inhibitor protein: structure, function, regulation of cell signaling, and pivotal role in apoptosis. Adv Cancer Res, 91 (2004), pp. 169-200

[74] E. Laville, T. Sayd, M. Morzel, S. Blinet, C. Chambon, J. Lepetit, et al.. Proteome changes during meat aging in tough and tender beef suggest the importance of apoptosis and protein solubility for beef aging and tenderization. J Agric Food Chem, 57 (22) (2009), pp. 10755-10764

[75] F. Yang, X. Sun, W. Beech, B. Teter, S. Wu, J. Sigel, et al. Antibody to caspase-cleaved actin detects apoptosis in differentiated neuroblastoma and plaque-associated neurons and microglia in Alzheimer's disease. Am J Pathol, 152 (2) (1998), pp. 379-389

[76] H. Huang, M.R. Larsen, R. Lametsch. Changes in phosphorylation of myofibrillar proteins during postmortem development of porcine muscle. Food Chem, 134 (2012), pp. 1999-2006

[77] T. Iwasaki, T. Katayama, K. Kohama, Y. Endo, T. Sawasaki. Myosin phosphatase is inactivated by caspase- 3 cleavage and phosphorylation of myosin phosphatase targeting subunit 1 during apoptosis. Mol Biol Cell, 24 (6) (2013), pp. 748-756

[78] A. Weins, K. Schwarz, C. Faul, L. Barisoni, W.A. Linke, P. Mundel. Differentiation- and stress-dependent nuclear cytoplasmic redistribution of myopodin, a novel actin-bundling protein. J Cell Biol, 155 (3) (2001), pp. 393-404

[79] C. Faul, A. Dhume, A.D. Schecter, P. Mundel. Protein kinase A, $\mathrm{Ca}^{2+} /$ calmodulin-dependent kinase II, and calcineurin regulate the intracellular trafficking of myopodin between the Z-disc and the nucleus of cardiac myocytes. Mol Cell Biol, 27 (23) (2007), pp. 8215-822

[80] M. Sanchez-Carbayo, K. Schwarz, E. Charytonowicz, C. Cordon-Cardo, P. Mundel. Tumor suppressor role for myopodin in bladder cancer: loss of nuclear expression of myopodin is cellcycle dependent and predicts clinical outcome. Oncogene, 22 (34) (2003), pp. 5298-5305

[81] M. Merad-Boudia, A. Nicole, D. Santiard-Baron, C. Saille, I. Ceballos-Picot. Mitochondrial impairment as an early event in the process of apoptosis induced by glutathione depletion in neuronal cells: relevance to Parkinson's disease. Biochem Pharmacol, 56 (1998), pp. 645-655 
[82] C. Lu, J.S. Armstrong. Role of calcium and cyclophilin d in the regulation of mitochondrial permeabilization induced by glutathione depletion. Biochem Biophys Res Commun, 363 (2007), pp. 572-577

[83] T. Takatani, K. Takahashi, Y. Uozumi, E. Shikata, Y. Yamamoto, T. Ito, et al. Taurine inhibits apoptosis by preventing formation of the Apaf-1/caspase-9 apoptosome. Am J Physiol Cell Physiol, 287 (2004), pp. 949-953

[84] J. Das, A. Roy, P.C. Sil. Mechanism of the protective action of taurine in toxin and drug induced organ pathophysiology and diabetic complications: a review. Food Funct, 3 (2012), pp. $1251-1264$

[85] J. Jumper, J.E. Kalns, K. Batey, R. Lane, J. Reed. The 3-nitrotyrosine marker of apoptosis shows time-dependent and tissue-specific variation in a porcine retinal laser injury model. Investig Ophthalmol Vis Sci, 43 (2002) [E-Abstract 4528]

[86] N. Moulian, F. Truffault, Y.M. Gaudry-Talarmain, A. Serraf, S. Berrih-Aknin. In vivo and in vitro apoptosis of human thymocytes are associated with nitrotyrosine formation. Blood, 97 (11) (2001), pp. 3521-3530

[87] G.L. Squadritoa, W.A. Pryor. Oxidative chemistry of nitric oxide: the roles of superoxide, peroxynitrite, and carbon dioxide. Free Radic Biol Med, 25 (4-5) (1998), pp. 392-403

Corresponding author at: Tuscia University, Largo dell'Università snc, 01100 Viterbo, Italy. Tel.: + 390761357 100; fax: + 390761357630 . 